\title{
Contrasting effects of ocean acidification on tropical fleshy and calcareous algae
}

Despite the heightened awareness of ocean acidification (OA) effects on marine organisms, few studies empirically juxtapose biological responses to $\mathrm{CO}_{2}$ manipulations across

functionally distinct primary producers, particularly benthic algae. Algal responses to OA may vary because increasing $\mathrm{CO}_{2}$ has the potential to fertilize photosynthesis but impair biomineralization. Using a series of repeated experiments on Palmyra Atoll, simulated OA effects were tested across a suite of ecologically important coral reef algae, including five fleshy and six calcareous species. Growth, calcification and photophysiology were measured for each species independently and metrics were combined from each experiment using a meta-analysis to examine overall trends across functional groups categorized as fleshy, upright calcareous, and crustose coralline algae (CCA). The magnitude of the effect of OA on algal growth response varied by species, but the direction was consistent within functional groups. Exposure to OA conditions generally enhanced growth in fleshy macroalgae, reduced net calcification in upright calcareous algae, and caused net dissolution in CCA. Additionally, three of the five fleshy seaweeds tested became reproductive upon exposure to OA conditions. There was no consistent effect of OA on algal photophysiology. Our study provides experimental evidence to support the hypothesis that OA will reduce the ability of calcareous algae to biomineralize. Further, we show that $\mathrm{CO}_{2}$ enrichment either will stimulate population or somatic growth in some species of fleshy macroalgae. Thus, our results suggest that projected OA conditions may favor non-calcifying algae and influence the relative dominance of fleshy macroalgae on reefs, perpetuating or exacerbating existing shifts in reef community structure. 
2 Maggie Dorothy Johnson*๋, Nichole N. Price ${ }^{\dagger}$, Jennifer E. Smith

3 Center for Marine Biodiversity and Conservation, Marine Biology Research Division, Scripps

4 Institution of Oceanography, La Jolla, CA 92093-0202, USA

5 *Corresponding author: Maggie D. Johnson

6 These authors contributed equally to this study.

7 Address: Scripps Institution of Oceanography 0202, University of California, San Diego, 9500

8 Gilman Drive, La Jolla, CA 92093-0202, USA

9 Phone: (207) 542-6909

10 E-mail: mdjohnson@ucsd.edu 


\section{INTRODUCTION}

12 Changes in ocean chemistry associated with anthropogenic carbon dioxide $\left(\mathrm{pCO}_{2}\right)$

13 emissions, a process known as ocean acidification (OA) (Kleypas et al., 1999; Orr et al., 2005),

14 have raised widespread concern for the survival and persistence of marine biota (Kleypas et al.,

15 1999; Hoegh-Guldberg et al., 2007). Identifying the groups of organisms that will be susceptible

16 to rapid OA versus those that may be resistant has prompted numerous studies (Ries, Cohen \&

17 McCorkle, 2009; Kroeker et al., 2010; Kroeker et al., 2013). To date, research has focused on

18 understanding how reductions in the saturation state $(\Omega)$ of calcium carbonate $\left(\mathrm{CaCO}_{3}\right)$ and

19 seawater $\mathrm{pH}$ associated with OA will impact the growth and physiology of commercially

20 important calcifying organisms or entire ecosystems, such as coral reefs, that build carbonate

21 platforms (Kleypas et al., 1999; Andersson \& Gledhill, 2013). However, examination of a wider

22 taxonomic representation, including those that calcify and those that do not, within and across

23 ecosystems is critical to developing ecological predictions of community-level responses to OA.

24 The changes in the carbonate system have important implications for marine calcifiers,

25 namely that OA may inhibit the ability of these species to grow, develop, reproduce and sustain

26 themselves within a community, although plasticity in organismal responses indicates that some

27 species may have wider tolerance limits (Doney et al., 2009; Kroeker et al., 2010; Kroeker et al.,

28 2013; Johnson, Moriarty \& Carpenter, 2014). Mounting evidence from coral reefs suggests that

29 decreasing carbonate saturation $(\Omega)$ has negative effects on calcification (Langdon \& Atkinson,

30 2005; Doney et al., 2009; Andersson \& Gledhill, 2013), reproductive success (Albright, 2011),

31 and competitive strength (Diaz-Pulido et al., 2011) of scleractinian corals. However, less attention

32 has been given to the response of tropical marine primary producers to rising oceanic $\mathrm{CO}_{2}$,

33 particularly fleshy and calcareous benthic macroalgae which are also among the most dominant

34 constituents of the coral reefs benthos. 
The future trajectory of coral reefs may be influenced by concurrent effects of OA on both

36 fleshy and calcified algae (reviewed in Koch et al., 2013), which serve key functional roles in

37 reef systems in addition to competing with corals for space and resources. Calcareous algae

38 contribute to framework development and some are active reef builders that account for up to

$3990 \%$ of living benthic cover on reefs (Tribollet \& Payri, 2001). Crustose coralline algae (CCA)

40 serve important ecological functions on reefs by contributing to primary production and

41 carbonate production (Chisholm, 2003), producing settlement cues for coral larvae (Harrington et

42 al., 2004; Price, 2010), and maintaining structural integrity of the framework by acting as reef

43 cement (Camoin \& Montaggioni, 1994). Calcareous green algae, such as Halimeda spp., are a

44 major source of primary production and $\mathrm{CaCO}_{3}$ (Rees et al., 2007) due to their fast growth and

45 turnover rates (Smith et al., 2004), and are a preferred food source for many coral reef fishes

46 (Mantyka \& Bellwood, 2007; Hamilton et al., 2014). Fleshy macroalgae include a highly diverse

47 group of seaweed species that act as a source of food for higher trophic levels and directly

48 compete with corals for space (McCook, Jompa \& Diaz-Pulido, 2001) on the reef benthos. Some

49 fleshy macroalgae produce toxic allelochemicals which can kill corals upon contact (Rasher et

50 al., 2012) while others may transmit coral disease (Nugues et al., 2004) or affect microbial

51 assemblages associated with the coral holobiont via release of dissolved organic carbon (Smith et

52 al., 2006; Haas et al. 2013; Nelson et al., 2013). Furthermore, the relative balance of calcifiers to

53 fleshy macroalgae is important for reef resilience (Hughes et al., 2010). Increased cover of fleshy

54 macroalgae, associated with anthropogenic disturbances such as poor water quality (Fabricius,

55 2005) and overfishing, is often used as an indicator of deteriorating reef health (Hughes, 1994).

56 Given the important roles that calcareous and fleshy algae serve in the structure and function of

57 coral reef ecosystems, it is critical to identify the potential differential effects of OA on these

58 functionally distinct groups. 
60 calcareous and fleshy algae, namely on photosynthesis and biomineralization. In terrestrial

61 systems, rising atmospheric $\mathrm{CO}_{2}$ can fertilize primary producers and enhance production

62 (Ainsworth \& Long, 2005), but in marine ecosystems, photosynthesizers have access to other

63 relatively abundant carbon species, such as bicarbonate $\left(\mathrm{HCO}_{3}^{-}\right)$, that can be used for

64 photosynthesis. The potential for $\mathrm{CO}_{2}$ fertilization of marine primary producers is likely

65 contingent on species-specific mechanisms of carbon acquisition, influenced by the activity of

66 carbon concentrating mechanisms (CCMs) (Giordano, Beardall \& Raven, 2005; Raven et al.,

67 2011; Koch et al., 2013). Laboratory manipulations and field studies from temperate and

68 Mediterranean ecosystems (Hall-Spencer et al., 2008; Porzio, Buia, Hall-Spencer, 2011) suggest

69 that OA may enhance carbon fixation (Kroeker et al., 2010; Cornwall et al., 2012; Kroeker et al.,

70 2013) and photosynthesis in fleshy algae resulting in increases in algal growth rates (Gao et al.,

71 1991; Kubler, Johnston \& Raven, 1999; Cornwall et al., 2012). However, variations in

72 interspecific responses may depend on the extent to which a species is presently carbon-limited

73 (Harley et al., 2012; Koch et al., 2013). The photosynthetic response of seaweeds to OA is

74 poorly understood in part because data on the presence, absence, or activity level of CCMs is

75 often lacking for many tropical species (Hurd et al., 2009; Raven et al., 2011). Although much of

76 the literature on $\mathrm{OA}$ effects on marine algae has shown that $\mathrm{CO}_{2}$ enrichment enhances

77 photosynthesis in phytoplankton and phanerograms (Riebesell et al., 1997; Palacios \&

78 Zimmerman, 2007; Gattuso \& Hansson, 2011), the photosynthetic response of seaweeds to OA

79 has been highly variable across experiments (Koch et al., 2013) and sometimes negative for

80 calcified species (Anthony et al., 2008; Sinutok et al., 2011; Sinutok et al., 2012).

81 Conversely, OA effects on skeletal production in calcareous algae have been studied in

82 more detail and changes in carbonate chemistry (i.e. lower $\mathrm{pH}$, lower carbonate availability, and

83 decreased $\mathrm{CaCO}_{3}$ saturation state) have been shown to inhibit calcification in many species. The 
84 effects of OA on calcification in marine organisms may be influenced by the ability for a species

85 to control carbonate chemistry at the intracellular or extracellular site of calcification (Ries,

86 Cohen \& McCorkle, 2009). A decrease in $\Omega$ in the external environment associated with OA

87 could make biogenic $\mathrm{CaCO}_{3}$ crystal precipitation more difficult. When $\Omega$ decreases below the

88 saturation horizon $(<1) \mathrm{CaCO}_{3}$ dissolution is thermodynamically favored (Milliman et al., 1999).

89 This saturation horizon is influenced by temperature, pressure, and mineralogy (Feely et al.,

90 2004; Orr et al., 2005), and net dissolution and calcification can occur both above and below this

91 threshold, respectively, depending on the organism and the environment (Milliman et al., 1999).

92 CCA may be some of the most sensitive calcifiers to OA because they secrete high Mg-calcite,

93 the most soluble polymorph of $\mathrm{CaCO}_{3}$ (Morse, Andersson \& Mackenzie, 2006; Andersson,

94 Mackenzie \& Bates, 2008). Other studies have found that OA decreases CCA calcification

95 (Semesi, Kangwe \& Bjork, 2009; Johnson \& Carpenter, 2012; Comeau, Carpenter \& Edmunds,

96 2013a; Comeau et al., 2013b; Johnson, Moriarty \& Carpeneter., 2014), structural integrity

97 (Ragazzola et al., 2012) and increases mortality and that these effects that may be exacerbated by

98 warming temperatures (Anthony et al., 2008; Martin \& Gattuso, 2009; Diaz-Pulido et al., 2012;

99 Martin et al., 2013) or increased solar UV radiation (Gao \& Zheng, 2010). The articulated

100 calcareous green algae Halimeda spp. have been shown to be both sensitive (Sinutok et al., 2011;

101 Sinutok et al., 2012) and insensitive to OA (Comeau et al., 2013b), where the direction and

102 magnitude of the response of Halimeda to OA varies among species (Ries, Cohen \& McCorkle,

103 2009; Price et al., 2011; Comeau et al., 2013b). Negative effects of OA on calcification of CCA

104 and Halimeda spp. may have serious implications for carbonate production and framework

105 stability on coral reefs because they are often common members of 'intact' benthic reef

106 communities (Sandin et al., 2008; Williams et al. 2013).

107 The primary objective of our study was to determine if there are consistent, differential

108 responses of fleshy and calcareous tropical marine algae to OA using parallel, replicated 
109

110

111

112

113

114

115

116

117

118

119

120

121

122

123

124

125

126

127

128

129

130

131

132

experimental manipulations. On Palmyra Atoll in the northern Line Islands, five common species of fleshy algae and six species of calcareous algae were exposed to $\mathrm{CO}_{2}$ levels expected by the year 2100 under a business-as-usual carbon emissions scenario (Meinshausen et al., 2011). In particular, the hypotheses tested were that, even with variation in species-specific physiological responses, elevated $\mathrm{CO}_{2}, 1$ ) reduces net calcification across calcareous algae but, 2) stimulates growth of fleshy algae by enhancing photosynthesis. This study provides one of the first efforts to quantify OA effects on multiple species of both calcareous and fleshy algae from a coral reef environment, and provides insight into the effects of OA on a suite of algae that are important in the structure and function of coral reefs.

\section{MATERIALS AND METHODS}

\section{Study site and species}

All experiments were conducted on Palmyra Atoll in the Northern Line Islands, central Pacific, in the recently established Pacific Remote Island Areas Marine National Monument (PRIAMNM) protected by the US Fish and Wildlife Refuge. Due to its isolation $(\sim 1,700 \mathrm{~km}$ south-southwest of Hawaii) and lack of permanent human residence, Palmyra's coral reefs are considered relatively healthy and are dominated by reef builders (Sandin et al., 2008; Williams et al., 2013). The remote nature of the field station limits research excursions to a few weeks at a time. Due to the absence of potentially confounding local anthropogenic impacts, Palmyra provides a unique setting for global change experiments.

To explore the effects of OA on different algal functional groups, eleven common species of algae were used in $\mathrm{CO}_{2}$ enrichment experiments (see Sandin et al., 2008 and Williams et al., 2013 for relative abundances). Algae were categorized into three functional groups: fleshy macroalgae (Acanthophora spicifera, Caulerpa serrulata, Dictyota bartayresiana, Hypnea pannosa, and Avrainvillea amadelpha), upright calcareous algae (Halimeda taenicola, Halimeda 
133

opuntia, Galaxaura rugosa, and Dichotomaria marginata), and crustose coralline algae (CCA:

134 Lithophyllum prototypum, formerly Titanoderma prototypum, and Lithophyllum sp.) (Fig. 1,

135 Table S1). Specimens were collected via SCUBA at a depth of $\sim 5 \mathrm{~m}$ from the shallow western

136 terrace $\left(5^{\circ} 53.1696^{\prime} \mathrm{N}, 162^{\circ} 7.5756^{\prime} \mathrm{W}\right)$, excluding L. prototypum. L. prototypum was collected

137 at a depth of $\sim 10 \mathrm{~m}$ from the southern fore reef $\left(5^{\circ} 53.7906^{\prime} \mathrm{N}, 162^{\circ} 7.6859^{\prime} \mathrm{W}\right)$ where the species

138 is abundant. Except for the corallines, which were collected as free-living rhodoliths, individuals

139 were removed at the holdfast or from rhizoids in order to minimize stress. Coralline rhodoliths

140 were comprised of $100 \%$ live coralline cover, and no bare carbonate was exposed to the

141 potentially corrosive conditions. Samples were cleaned carefully of epiphytes with a soft-bristled

142 brush and allowed to acclimate for at least one day in fresh, ambient seawater.

\section{Experimental conditions and seawater chemistry}

144

145

146

147

148

149

150

151

152

153

154

155

156
To explore the effects of OA on growth, calcification and photophysiology of benthic algae, $\mathrm{CO}_{2}$ enrichment experiments were conducted for $\sim 2$ weeks in July of 2010, and September of 2009, 2011, and 2012 (see Table S2 for experiments across years). Experimental aquariums (glass jars) held $700 \mathrm{~mL}$ of seawater collected from offshore and an individual alga ( $\sim 2 \mathrm{~g}$ live tissue). Seawater was treated continuously with either air or $\mathrm{CO}_{2}$ enriched gas for several hours prior to experimentation and changed (100\%) every 48 hours to prevent nutrient limitation and to maintain treatment conditions (sensu Price et al., 2011).

The effects of projected OA were simulated by micro-bubbling either pre-mixed air enriched with $\mathrm{CO}_{2}$ to $\sim 1,000 \mu \mathrm{atm}$ into treatment aquariums (OA treatment) or ambient air into control aquariums. Clear polycarbonate lids reduced atmospheric equilibration, evaporation, and rainwater incursion. Air and $\mathrm{CO}_{2}$ enriched gas were bubbled continuously into treatment aquariums through wooden air stones that were placed at the bottom, center of experimental replicates. The continuous bubbling within a relatively small volume facilitated thorough mixing 
157 of the seawater within the jars. It was not possible to measure water flow within the contained

158 jars however gas was adjusted to flow into experimental aquariums at a constant rate. Samples

159 sizes varied by experiment and the availability of samples, but ranged from 4 replicates per

160 treatment/species in 2009 to 10 in 2012 (Table S2). Additionally, aquariums without algae were

161 maintained in all experiments to determine if algal metabolism affected carbonate chemistry and

162 altered treatment conditions.

163 Aquariums were partially submerged in flow-through seawater baths under natural

164 sunlight with shade cloth screens to simulate in situ temperature and irradiance levels at $5 \mathrm{~m}$

165 depth (Table S2). Temperature and light intensity within aquariums were monitored every 15

166 min with data loggers (Onset, HOBO Pendant Temperature Light/Data Logger) for the duration

167 of the experiments. Light intensity was measured in Lux, and converted to photosynthetically

168 active radiation (PAR) with the following conversion: $1 \mu \mathrm{mol}$ quanta $(400-700 \mathrm{~nm}) \mathrm{m}^{-2} \mathrm{~s}^{-1}=51.2$

169 lux (Valiela, 1984). This conversion was validated by additional in situ PAR measurements made

170 at the collection site, using an underwater spherical quantum sensor (LICOR, LI-193). In 2009

171 and 2010, oxygen $\left(\mathrm{O}_{2}\right.$, polarographic electrode, $\left.\pm 0.2 \mathrm{mg} \mathrm{L}^{-1}\right)$, temperature $\left( \pm 0.15^{\circ} \mathrm{C}\right)$, salinity $( \pm$

$1720.1 \mathrm{psu})$ and $\mathrm{pH}_{\mathrm{SW}}( \pm 0.2)$ were monitored with a handheld meter (YSI Environmental Quatro).

173 In 2011 and $2012, \mathrm{O}_{2}\left( \pm 0.01 \mathrm{mg} \mathrm{L}^{-1}\right)$, temperature $\left( \pm 0.3{ }^{\circ} \mathrm{C}\right)$, and $\mathrm{pH}_{\mathrm{SW}}( \pm 0.1)$ were measured

174 with a Hach Lange HQ40 portable multi-parameter meter (IntelliCAL PHC101 Standard Gel

175 Filled pH Electrode and IntelliCAL LDO101 Standard Luminescent Dissolved Oxygen LDO

176 Optode). The $\mathrm{pH}$ probe was calibrated daily with certified Tris buffer (provided by Andrew

177 Dickson, SIO). Using certified Tris buffer as a reference improved the accuracy of $\mathrm{pH}$ probe

178 measurements to \pm 0.001 . In each year, measurements were recorded from all aquariums in the

179 evening $(1800-2000)$ of each day (Table 1$)$. 
181 were collected from empty aquariums (controls) and a subset of experimental aquariums from

182 both treatment levels at multiple time points during all experiments (in 2009 only samples from

183 empty aquariums were collected). Samples were collected by siphoning treatment water into 500

$184 \mathrm{~mL}$ Corning-brand Pyrex sample bottles and fixed with $200 \mu \mathrm{L}$ saturated $\mathrm{HgCl}_{2}$, leaving a $1 \%$

185 head space. Water samples were transported to Scripps Institution of Oceanography (SIO) for

186 standard carbonate chemical analyses, (SOP, sensu Dickson, Sabine \& Christian, 2007) in the lab

187 of Dr. Andrew Dickson. $\mathrm{A}_{\mathrm{T}}$ was determined using an open-cell titrator (Metrohm Dosimat Model

188 665) and Metrohm potentiometric $\mathrm{pH}(\mathrm{SOP} 3 \mathrm{~b})$, and $\mathrm{C}_{\mathrm{T}}$ was determined with a Single Operator

189 Multi-parameter Metabolic Analyzer (SOMMA) coulometer (SOP 2) (Dickson, Sabine \& Christian,

190 2007). From the measurements of $A_{T}$ and $C_{T}$, the remaining carbonate parameters were calculated

191 using the computer program CO2SYS (Table S3) (Pierrot, Lewis \& Wallace, 2006). The average

192 difference $( \pm \mathrm{SE})$ between the mean measured $\mathrm{pH}_{\mathrm{Sw}}$ and the mean $\mathrm{pH}_{\mathrm{Sw}}$ calculated from

193 measurements of $\mathrm{A}_{\mathrm{T}}$ and $\mathrm{C}_{\mathrm{T}}$ was $0.1( \pm 0.05)(\mathrm{n}=32)$.

\section{$194 \mathrm{CO}_{2}$ effects on growth and calcification}

195 Growth of fleshy algae was measured as the change in wet weight over time (to the

196 nearest $0.01 \mathrm{~g})$. Samples were spun in a salad spinner (10 revolutions) and then gently blotted

197 dry with paper towels immediately prior to obtaining weights. Net growth and calcification were

198 measured using the change in buoyant weight (Davies, 1989), where all calcareous species were

199 weighed to the nearest $0.001 \mathrm{~g}$ while suspended (from the weigh-below on a balance) in a basket

200 submerged in ambient seawater; a technique that works well for upright calcareous algae (Price et

201 al., 2011). Any segments shed during the course of the experiment were weighed along with the

202 intact thallus. Buoyant weight was converted to actual weight based on the density of seawater

203 and the density of the respective $\mathrm{CaCO}_{3}$ polymorph. Growth and calcification rates were 
204 calculated by the change in weight over the experiment, with rates normalized to initial thallus

205 weight and number of days in treatment conditions, expressed as change in weight per day ( $\mathrm{mg} \mathrm{g}^{-}$ $206{ }^{1}$ day $\left.^{-1}\right)$.

\section{$207 \mathrm{CO}_{2}$ effects on photophysiology}

To assess the effect of $\mathrm{CO}_{2}$ enrichment on algal photophysiology, photosynthetic parameters were measured fluorometrically with a red Pulse Amplitude Modulated Fluorometer (PAM) (Walz). The fiber optic probe was clipped to the thallus halfway up the branch on an unepiphytized portion of tissue with the "dark leaf clip". Rapid light curves (RLCs) were generated by exposing algal tissue to 8 incremental steps of increasing irradiance from $0-436 \mu \mathrm{M}$ photons $\mathrm{m}^{-2} \mathrm{~s}^{-1}$ in $2009,0-533 \mu \mathrm{M}$ photons $\mathrm{m}^{-2} \mathrm{~s}^{-1}$ in 2010 , and $0-614 \mu \mathrm{M}$ photons $\mathrm{m}^{-2} \mathrm{~s}^{-1}$ in 2011 , with $10 \mathrm{~s}$ at each light step (Saroussi \& Beer, 2007). Replicate RLCs were generated in 2009 (3 RLCs per individual) and 2010 (2 RLCs per individual), and one RLC was generated for samples in 2011. Due to variation in experimental setup and PAR conditions across experiments, RLC intensities were higher than experimental PAR intensities in 2009 and 2010 and lower than experimental conditions in 2011 (Table S2). No RLCs were conducted on H. taenicola and $A$. amadelpha in 2012 because of time constraints. Using this approach of short illumination interval RLCs $(<1 \mathrm{~min})$, we were interested in relative comparisons of photophysiological performance between treatments (Enriquez \& Borowitzka, 2010). Photosynthetic parameters were calculated from each RLC, and where RLCs were repeated on an individual, parameters were averaged for each individual before further statistical analyses.

\section{Statistical Analyses}

225 To explore the effects of $\mathrm{CO}_{2}$ enrichment on growth and calcification, separate t-tests for 226 each species compared responses between control and experimental treatments. Certain species 
227 were experimentally manipulated in multiple years; to examine overall effects on species

228 independent of experimental year, data across years were pooled. Additional independent t-tests

229 were run in each year for those species, because the experimental setup and sample size varied

230 slightly from year-to-year. Prior to analysis conducted in statistical software JMP v.10, data were

231 tested for the assumptions of normality and homogeneity of variances with the Shapiro-Wilks test 232 and diagnostic q-q plots.

233 To examine photophysiological response to $\mathrm{CO}_{2}$ enrichment, the electron transport rates

234 (ETR) from each RLC was plotted against irradiance and fit to a three parameter model (Frenette

235 et al. 1993) to estimate the initial slope of the curve $\left(\alpha, \mu \mathrm{M}\right.$ electrons $\mu \mathrm{M}$ photons $\left.{ }^{-1}\right)$, the

236 maximum relative electron transport rate $\left(\mathrm{rETR}_{\mathrm{Max}}, \mu \mathrm{M}\right.$ electrons $\left.\mathrm{m}^{-2} \mathrm{~s}^{-1}\right)$, and photoinhibition $(\beta$,

$237 \mu \mathrm{M}$ electrons $\mu \mathrm{M}$ photons ${ }^{-1}$ ) (Platt, Gallegos \& Harrison, 1980). Mean parameter estimates were

238 averaged across samples within a treatment level for each species. In 2009 and 2010, several

239 RLCs were generated for an individual alga; parameters were averaged within an individual

240 before treatment effects were explored. The analyses were conducted using the software

241 GraphPad Prism (v.6) and in all cases the model fit the data well with $\mathrm{R}^{2}>0.90$ and $\mathrm{p}<0.001$.

242 Parameters were compared for each species between treatments using independent t-tests as

243 described above.

\section{Meta-analysis}

245 Meta-analyses were used to combine data across independent experiments and to explore

246 potential differences in functional group responses to OA. Each species was categorized as

247 fleshy macroalgae, upright calcareous algae, or CCA. Species that became sexually reproductive

248 during experiments (A. spicifera, A. amadelpha, C. serrulata 2011) were not included in the

249 meta-analysis because a large portion of the algal thallus senesced, or for holocarpic species the

250 entire thallus disintegrated, after gamete/spore release and it was not possible to differentiate 
251 between the effects of reproduction versus OA treatment on algal biomass. Species tested across

252 multiple years were included as independent data sets, yielding 3 fleshy macroalgae, 6 upright

253 calcareous algae, and 3 CCA representatives. A random-effects model of standardized mean

254 differences (Cooper, Hedges \& Valentine, 1994) was used to estimate within and across

255 experiments variance components; effect size was weighted both by sample size and pooled

256 standard deviation. A one-tailed z-test of significance (against zero) of the mean effect size of

$257 \mathrm{CO}_{2}$ enrichment was used for algal growth and calcification responses. OA treatments were

258 expected to enhance fleshy algal growth $\left(\mathrm{H}_{0}\right.$ : mean effect size $\left.\leq 0\right)$ and decrease algal

259 calcification $\left(\mathrm{H}_{0}\right.$ : mean effect size $\left.\geq 0\right)$. There was no a priori expectation of photosynthetic

260 responses to OA and thus a two-tailed z-test was used for the meta-analyses of photosynthetic

261 parameters (see Supplemental Information for details).

\section{RESULTS}

\section{Experimental conditions}

$264 \mathrm{CO}_{2}$ enrichment treatments effectively simulated near future seawater carbonate chemistry

265 and OA as compared to present-day ambient air controls (Table 1). Biological activity (i.e.

266 photosynthesis and respiration) introduced variability into carbonate chemistry conditions in both

267 ambient and high $\mathrm{pCO}_{2}$ treatments (Table S3). Diel variability in carbonate chemistry was not

268 characterized, however, based on previous studies photosynthesis likely caused higher $\mathrm{pH}$ during

269 the day, whereas respiration reduced $\mathrm{pH}$ at night (Ohde \& van Woesik, 1999). Discrete water

270 samples and $\mathrm{pH}$ probe measurements were collected at approximately the same time of day

271 (2000) during all experiments. The average difference ( \pm SE) between the mean measured $\mathrm{pH}_{\mathrm{SW}}$

272 and the mean $\mathrm{pH}_{\mathrm{SW}}$ calculated from measurements of $\mathrm{A}_{\mathrm{T}}$ and $\mathrm{C}_{\mathrm{T}}$ was $0.1( \pm 0.05)(\mathrm{n}=32)$.

273 Considering the robustness of $\mathrm{pH}$ probe measurements in comparison to certified Tris buffer $( \pm$

2740.001 ), the relatively small difference between measured and calculated $\mathrm{pH}$, and the frequency of 
275 samples for measured $\mathrm{pH}(\mathrm{n}=9-17)$ (Table 1) versus calculated $\mathrm{pH}(\mathrm{n}=2-4)$ (Table S3),

276 measured $\mathrm{pH}_{\mathrm{Sw}}$ is the most appropriate parameter to describe differences in carbonate chemistry

277 among experimental replicates. Most other physical conditions were consistent across years, but

278 due to changes in experimental facilities, irradiance levels were higher and more representative of

279 shallow reef environs in 2011 and 2012; oxygen levels were also higher in those years (Table 1).

\section{Species-specific effects of $\mathrm{CO}_{2}$ enrichment on calcification and growth}

High $\mathrm{CO}_{2}$ conditions decreased net calcification rates in 4 of the 6 calcareous species, and

282 potentially enhanced net growth in 2 of the 5 fleshy species (Fig. 1; Table 2). $\mathrm{CO}_{2}$ enrichment

283 significantly decreased calcification in the red calcareous macroalga D. marginata (by $98 \%$ ), and

284 the two CCA Lithophyllum sp. (by 185\%) and T. prototypum (by 190\%) relative to controls

285 (Table 2). The response of the green calcareous algae in the genus Halimeda was species-

286 specific: the effect of $\mathrm{CO}_{2}$ enrichment on net calcification rates was negative for $H$. opuntia

287 (when repeated experiments were pooled) but negligible for H. taenicola (Table 2). $\mathrm{CO}_{2}$

288 enrichment significantly increased growth in the fleshy red macroalga $H$. pannosa (by 93\%)

289 relative to controls (Table 2). The fleshy brown macroalga D. bartayresiana showed slight but

290 non-significant increases in growth in high $\mathrm{CO}_{2}$ likely due to small sample size and lack of power

$291 \quad(\beta=0.46$; Table 2).

292 In addition to across species variability in the growth response, there was intra-specific

293 variation to $\mathrm{CO}_{2}$ enrichment across different years of experiments (Fig. 2). The trends and

294 absolute magnitude in growth responses remained the same for 2 of the 4 species tested over

295 multiple years. Irrespective of year, the calcareous green alga $H$. opuntia calcified significantly

296 less (by $14.55 \mathrm{mg} \mathrm{g}^{-1} \mathrm{~d}^{-1}$ in 2009 and $12.97 \mathrm{mg} \mathrm{g}^{-1} \mathrm{~d}^{-1}$ in 2011) under high $\mathrm{CO}_{2}$ conditions (Table

297 3), although the relative response varied by year. $H$. opuntia calcified $200 \%$ less at high $\mathrm{CO}_{2}$ than

298 ambient conditions and even experienced net dissolution in 2009 , but only calcified $50 \%$ less in 
2011 and experienced net growth, despite the same high $\mathrm{CO}_{2}$ conditions (Table S4).

300 Lithophyllum sp. showed a consistent response to $\mathrm{CO}_{2}$ treatment in direction and absolute and

301 relative magnitude across years. Lithophyllum sp. calcified $185 \%$ less at high $\mathrm{CO}_{2}$ in both 2009

302 and 2011 (Table S4). H. taenicola calcified $89 \%$ less at high $\mathrm{CO}_{2}$ relative to controls in 2009, but

303 there was no significant difference in calcification during the 2010 and 2012 experiments (Table

304 3). C. serrulata grew significantly more at high $\mathrm{CO}_{2}$ in the 2010 experiment, however in $2011 \mathrm{C}$.

305 serrulata grew less in the $\mathrm{CO}_{2}$ enrichment treatment than in ambient conditions (Table 3).

306 Several fleshy macroalgal species became reproductive in $\mathrm{CO}_{2}$ treatments over the course

307 of our study, as evidenced by the presence of fertile tissue which eventually released gametes or

308 spores leaving behind only a small portion of the vegetative thallus. All samples of A. spicifera

309 and A. amadelpha released spores or gametes, respectively, upon exposure to treatment

310 conditions. In 2011, C. serrulata also reproduced, causing tissue loss in both ambient and $\mathrm{CO}_{2}$

311 treatments; $40 \%$ of Caulerpa individuals in the ambient treatment reproduced, whereas $100 \%$ of

312 Caulerpa samples in the $\mathrm{CO}_{2}$ enrichment treatments reproduced.

\section{Species-specific effects of $\mathrm{CO}_{2}$ enrichment on photophysiology}

314 Exposure to $\mathrm{CO}_{2}$ treatments had no detectable effect on relative photophysiology of the 9

315 species tested, with a few exceptions (Fig. 3). $\mathrm{CO}_{2}$ enrichment significantly increased the

316 maximum photosynthetic capacity $\left(\mathrm{rETR}_{\operatorname{Max}}\right.$ ) in the calcareous red alga G. rugosa (Fig. 3A, Table

317 2) relative to the control. In the fleshy red alga $A$. spicifera, $\mathrm{rETR}_{\text {Max }}$ was significantly lower

318 following exposure to high $\mathrm{CO}_{2}$, however, these individuals had reproduced during the

319 experiment and the remaining vegetative tissue following gamete release was not representative

320 of healthy algal tissue. In the calcareous green alga H. taenicola, the initial slope of the RLC $(\alpha)$

321 was significantly depressed after $\mathrm{CO}_{2}$ enrichment (Fig. 3B, Table 2). There was no evidence of

322 photoinhibition ( $\beta$ ) in any of the species tested (Fig. 3C, Table 2). 


\section{Meta-analysis of experiments across years}

324

325

326

327

328

329

330

331

332

333

334

335

Experimental effects were combined across species to assess the consistency of

physiological responses to $\mathrm{CO}_{2}$ enrichment within different algal functional groups using meta-

analyses. The mean effect size for calcification and growth was significantly greater than zero for

fleshy species, but significantly less than zero for both groups (upright and encrusting) of

calcareous species (Table 4; Fig. 4A). There was no overall effect of $\mathrm{CO}_{2}$ enrichment on

photophysiology $\left(\mathrm{rETR}_{\max }, \alpha, \beta\right)$ relative to the control for algal functional groups (Fig. 4, Table

4). The variation between experiments was never significantly different from $0(\mathrm{Q} \leq 2.04, \mathrm{p}>$

0.05 for each functional group and response variable; Table 4), indicating that the inconsistencies

in PAR did not influence the overall response of fleshy versus calcareous algae to OA. Due to

the significant effect of $\mathrm{CO}_{2}$ enrichment on growth and calcification rates across experiments, and the lack of significant variation in the strength of this response, we pooled species across years to show overall trends in treatment responses (Fig. 1).

\section{DISCUSSION}

This series of experimental manipulations indicate that tropical algae respond differently

to $\mathrm{CO}_{2}$ enrichment depending on species and whether or not they are calcified. When combining data from multiple experiments, calcareous algae experienced a reduction in biomineralization while fleshy algae became more productive. The magnitude of algal growth and calcification responses to OA conditions varied by species, and occasionally, within a species over multiple experiments. In contrast, there was no effect of $\mathrm{CO}_{2}$ enrichment on algal photophysiology relative to controls as measured by short illumination RLCs. Furthermore, exposure to OA conditions initiated sexual reproduction in 3 out of 5 species of fleshy macroalgae tested. These 
345 results support the hypothesis that OA has differential effects on the growth of fleshy macroalgae 346 and the calcification of calcareous algae.

347 Biomineralization by seaweeds substantially contributes to carbonate production on

348 tropical reefs and these results suggest that OA may decrease reef formation and cementation

349 services provided by these often over-looked ecosystem engineers. In these experiments, OA

350 decreased calcification of calcareous green algae (H. opuntia and H. taenicola) and caused net

351 dissolution of calcareous red macrophytes and CCA (D. marginata, G. rugosa, Lithophyllum sp.,

352 and L. prototypum). Many other studies have reported decreased calcification as a consequence

353 of simulated OA for tropical (Table 5) and temperate calcareous algae even in milder

354 acidification scenarios than used in our study (see Koch et al., 2013 for review). However, much

355 of the previous work exploring OA effects on calcareous algae across ecosystems has focused on

356 the crustose coralline algae (family Corallinaceae) and this study is among the first to expand to

357 different taxonomic entities such as the lightly calcified red algae D. marginata and G. rugosa

358 (Table 5).

359 The results of this study indicate that calcareous algae calcified less after two weeks of

360 exposure to $\mathrm{CO}_{2}$ enrichment than ambient controls, but the response varied by functional group.

$361 \mathrm{CCA}$, which deposit the more soluble high $\mathrm{Mg}$-calcite (12-18\% $\mathrm{MgCO}_{3}$; Milliman, Gastner \&

362 Muller, 1971), experienced net dissolution in the OA treatments, where $\Omega_{\text {Mg-calcite }}$ was $\leq 1$ (using

363 the solubility constant estimated by Lueker, Dickson \& Keeling, 2000), despite assuming our

364 samples deposited the conservative lower range of $8 \% \mathrm{Mg}$ mole fraction. Intracellular dolomite

$365\left(\mathrm{CaMg}\left[\mathrm{CO}_{3}\right]_{2}\right)$, a stable form of carbonate, can be the source of $\mathrm{Mg}$ in other species of CCA and

366 actually reduces net thallus dissolution at higher skeletal mole fractions (Nash et al., 2012). The

367 exact mineral composition of the carbonate in our CCA species is unknown, but was not robust to

368 our treatment conditions. The calcareous upright algae all deposit aragonite and calcified less

369 under OA, but only experienced net dissolution in one instance. Differences in the magnitude of 
effects between calcareous species may be influenced by species-specific mechanisms of

371 calcification (Price et al., 2011; Comeau, Carpenter \& Edmunds, 2013a; Koch et al., 2013),

372 mineralogy of $\mathrm{CaCO}_{3}$ deposited (Ries, Cohen \& McCorkle, 2009), and potential compensatory or

373 antagonistic effects of high $\mathrm{CO}_{2}$ on photosynthesis (Table 5). Differences in within-species

374 susceptibility to OA demonstrate the complexity of how ocean acidification may influence

375 biological and chemical interactions in tropical marine primary producers. Within-species

376 responses across years of experiments may have been driven by changes in dissolution versus

377 calcification or by net growth rate, and the relative contribution of dissolution versus calcification

378 in influencing net effects of OA on organisms should be a focus in future studies.

379 Understanding the effects of OA on algal physiology is difficult because photosynthesis

380 and calcification are inextricably coupled. In the process of fixing carbon, algal photosynthesis

381 alters the intracellular environment in favor of $\mathrm{CaCO}_{3}$ precipitation (Borowitzka \& Larkum,

382 1976). In the external environment, photosynthesis also has the potential to alter carbonate

383 chemistry and to create conditions more favorable for calcification (Gattuso, Pichon \&

384 Frankignoulle, 1995; Anthony, Kleypas \& Gattuso, 2011; Smith et al., 2013). Fleshy macroalgae

385 that are currently carbon limited are hypothesized to be affected positively by increasing $\mathrm{CO}_{2}$

386 concentrations (Gao et al., 1991), which is demonstrated here, but these effects are species and

387 condition specific. Previous studies have documented both positive and negative effects of $\mathrm{CO}_{2}$

388 enrichment on growth in fleshy macroalgae (Table 5). Enhanced algal growth also has been

389 documented in situ in ecosystems near underwater volcanic vents where conditions of low $\mathrm{pH}$

390 and high $\mathrm{CO}_{2}$ facilitate communities dominated by fleshy organisms (Hall-Spencer et al., 2008;

391 Fabricius et al., 2011). It has been hypothesized that higher concentrations of dissolved $\mathrm{CO}_{2}$

392 would enhance fleshy macroalgal growth by stimulating photosynthesis. However, despite the

393 fact that fleshy algae grew more with high $\mathrm{CO}_{2}$ there was not a concurrent response in

394 photosynthetic parameters measured from chlorophyll fluorescence. While the fluorescence 
395 technique is used widely to monitor algal photophysiology, it can be highly variable (Edwards \& 396 Kim, 2010) and provides only an instantaneous snapshot of photophysiological function. Short 397 illumination RLCs ( $<1 \mathrm{~min})$ are not comparable to estimates obtained using oxygen evolution

398 from photosynthesis-irradiance curves because there is not sufficient time with RLCs for 399 organisms to reach steady-state flow of electrons (Enriquez \& Borowitzka, 2010). Thus, it may 400 not be the most suitable technique to assess the cumulative effects of $\mathrm{CO}_{2}$ enrichment on algal 401 photophysiology and more direct measures of photosynthesis are preferred. Predicting the response of primary producers to high $\mathrm{CO}_{2}$ is complex and may depend on 403 resource acquisition strategies that are species-specific and potentially plastic over time. The 404 primary substrate for the photosynthetic enzyme Rubisco in all marine algae is dissolved $\mathrm{CO}_{2}$.

405 Seaweeds must compensate for the slow rates of $\mathrm{CO}_{2}$ diffusion through seawater, as opposed to 406 air, as well as the higher concentration of $\mathrm{HCO}_{3}^{-}$compared to $\mathrm{CO}_{2}$. Some primary producers 407 have developed carbon concentrating mechanisms (CCM) that increase the concentration of $\mathrm{CO}_{2}$ 408 in the proximity of Rubisco (Raven, 1970). Thus, the presence or absence of CCMs may 409 influence species-specific responses to $\mathrm{CO}_{2}$ enrichment (Hurd et al., 2009; Koch et al., 2013), and 410 changes to CCM activity levels may explain the mixed responses of photosynthesis in the

411 literature, as well as the growth results documented here. One possible mechanism that may have 412 facilitated increased algal productivity under high $\mathrm{CO}_{2}$ in the present study, without concurrent 413 increases in $\mathrm{rETR}_{\mathrm{Max}}$ or $\alpha$, may have been an increase in algal energy reserves through down 414 regulation of energetically costly CCMs, noted in another tropical green macroalga (Liu, Xu \& 415 Gao, 2012) and phytoplankton (Eberlein, Van de Waal \& Rost, 2013). An additional alternative 416 hypothesis is that nitrate reductase activity, an enzyme that reduces nitrate to nitrite, can be 417 stimulated by $\mathrm{CO}_{2}$ (Hofmann, Straub \& Bischof, 2013), potentially releasing seaweed from 418 nitrogen resource limitation in oligotrophic coral reef ecosystems. Furthermore, photophysiology 419 should be assessed using more direct techniques in addition to RLCs such as measuring oxygen 
420

421

422

423

424

425

426

427

428

429

430

431

432

433

434

435

436

437

438

439

440

441

442

443

444

evolution rates, in order to accurately quantify photosynthetic rates. Predicting changes in

enzymatic activity is critical to understanding mechanisms behind species-specific responses to

OA, yet basic physiological descriptions are lacking for the majority of tropical algae, including the species used in the present study.

This and other studies have documented high variability among species in response to OA. However, there also was within species variability across years, suggesting that speciesspecific responses to OA may be context dependent. For example, due to logistical constraints experiments conducted in 2009 and 2010 had substantially lower daily mean irradiances than in 2011 and 2012 (ESM Table 2). Although mixing rates were consistent from year to year, flow rates in experimental aquariums were relatively low. Thus, care should be taken when extrapolating these biological responses to OA under higher water flow regimes. Few studies have experimentally tested the effects of both water flow and OA on coral reef algae, although flow rate has been shown to be an important factor influencing $\mathrm{pH}$ gradients within the diffusive boundary layer (DBL) (Hurd et al., 2011) and the response of some reef calcifiers to high $\mathrm{CO}_{2}$ (Anthony et al., 2013). Increasing DBL thickness, with decreasing water flow, may buffer organisms against changes in the carbonate chemistry of bulk seawater by providing a metabolically mediated microenvironment of higher $\mathrm{pH}$ within the DBL. Furthermore, the biological variability in carbonate conditions introduced by algal photosynthesis and respiration in the contained, aerated volume of water likely created a diel cycle in $\mathrm{pH}$ that may have approximated carbonate chemistry variability on a shallow reef flat (Hofmann et al., 2011). Variability in $\mathrm{pH}$ conditions has been shown to influence growth rates of coralline algae (Johnson, Moriarty \& Carpenter, 2014), therefore care should be taken when extrapolating the results from the present study to other systems. Diel cycles in carbonate chemistry were not characterized in this experiment, and have been infrequently included in descriptions of experimental conditions in many OA studies. However, the variability in all experimental 
conditions across this suite of experiments is far less than that of experiments combined in

446 several recent meta-analyses (Hendriks et al., 2010; Kroeker et al., 2010; Kroeker et al., 2013).

447 With the meta-analysis approach used here to explore effects of OA across experiments, we

448 accounted for the variability within and across experiments and found that OA treatment was a

449 significant driver of enhanced growth in fleshy macroalgae, and loss of calcified biomass in 450 upright calcareous algae and CCA.

451 Some within-species variability in response to OA treatment was due to the induction of

452 sexual reproduction following exposure to treatment conditions. Higher irradiance levels can

453 modulate the negative effects of high $\mathrm{CO}_{2}$ on algal responses to OA (Sarker et al., 2013; Yildiz et

454 al., 2013), including potentially triggering reproduction and may explain the inconsistent results

455 from year to year, specifically for $C$. serrulata. In 2011 the decrease in C. serrulata growth likely

456 was a result of the loss of algal tissue in individuals that became sexually reproductive upon

457 exposure to high $\mathrm{CO}_{2}$ and relatively higher irradiance. Similar reproductive responses to

458 treatment conditions were also noted for related $A$. amadelpha and for a red macroalga,

459 suggesting that there may be an interactive effect between irradiance levels and $\mathrm{CO}_{2}$

460 concentrations. Sexual reproduction in these taxa has been observed in Hawaii and the Caribbean

461 during the spring (Clifton \& Clifton, 1999; Smith, Hunter \& Smith, 2002). In all of these species,

462 a large portion of the algal thallus senesced after sexual reproduction, and for the green algae the

463 reproduction was clearly visible due to the loss of pigmentation following release of heavily

464 pigmented gametes or spores (Clifton \& Clifton, 1999). The typical progression of sexual

465 reproduction in Bryopsidales ranges from in 1-2 days (Clifton \& Clifton, 1999), and the

466 specimens did not show signs of reproduction prior to the experiment. Furthermore,

467 gametogenesis in C. serrulata has been shown to be induced either as a coping mechanism

468 (Williamson, 2010) or to maximize favorable conditions (Brawley \& Johnson, 1992).

469 Experiments were conducted outside the potential seasonal reproductive cycle of tropical algae, 
470

471 reproduction was induced by experimental conditions. An alternative explanation is that the

472 reproductive response may have been an artifact of experimental manipulation and stress

473 associated with rapid exposure to high $\mathrm{pCO}_{2}$. The rate of exposure to high $\mathrm{pCO}_{2}$ has been shown

474 to be an important determinant in the response of coralline algae to $\mathrm{CO}_{2}$ enrichment (Kamenos et 475

al., 2013). Future work should explore the effects of both rate and magnitude of $\mathrm{CO}_{2}$ enrichment on reproduction in fleshy macroalgae.

OA poses an ever-increasing global threat (Kleypas et al., 1999; Hoegh-Guldberg et al., 2007) to the ecological balance and stability of tropical reef systems via disparate effects on calcareous versus fleshy taxa (Hall-Spencer et al., 2008; Fabricius et al., 2011; Porzio, Buia \& Hall-Spencer, 2011). It is difficult to predict the specific responses of macroalgal taxa to $\mathrm{CO}_{2}$ enrichment; however, the patterns of response presented here suggest that growth of fleshy macroalgae on coral reefs may be stimulated by OA, while calcareous species may be depressed. Given that numerous other human impacts (overfishing, pollution, warming) negatively affect corals and other calcifying reef builders while enhancing the abundance of fleshy algae, our results suggest that OA may potentially exacerbate community shifts towards fleshy macroalgal dominated states. However, little is known about how reef species or communities will respond to the interactive effects of multiple stressors including OA. Given the importance of coral reefs for supporting biodiversity (Knowlton, 2001), as well as human populations and economies of coastal nations (Moberg \& Folke, 1999), it is imperative that we understand the scope of species responses to impending rapid climate change. 
491

492

493

494

495

496

497

498

500

501

502

503

504

505

506

507

508

509

510

511

512

513

514

515

516

517

518

519

520

521

522

523

524

525

526

\section{ACKNOWLEDGEMENTS}

We thank the U.S. Fish and Wildlife Service (USFWS) and The Nature Conservancy for

granting access to Palmyra Atoll and providing logistical support. The A. Dickson lab provided

chemical analyses and A. Meyer, K. Furby, J. Harris, S. Hamilton, S. Sandin, J. Tootell, and B.

Zgliczynski provided logistical field support. This research was conducted under the USFWS

special use permits 12533-09020, 12533-12011, and 12533-12012. Scripps Institution of

Oceanography (SIO) is a member of the Palmyra Atoll Research Consortium (PARC); this is

contribution number PARC-0XXX.

\section{REFERENCES}

Ainsworth EA, Long SP. 2005. What have we learned from 15 years of free-air $\mathrm{CO}_{2}$ enrichment (FACE)? A meta-analytic review of the responses of photosynthesis, canopy properties and plant production to rising $\mathrm{CO}_{2}$. New Phytologist 165:351-371.

Albright R. 2011. Reviewing the effects of ocean acidification on sexual reproduction and early life history stages of reef-building corals. Journal of Marine Biology 2011:1-14.

Andersson AJ, Gledhill D. 2013. Ocean acidification and coral reefs: effects on breakdown, dissolution, and net ecosystem calcification. Annual Review of Marine Science 5:321-348.

Andersson AJ, Mackenzie FT, Bates NR. 2008. Life on the margin: implications of ocean acidification on Mg-calcite, high latitude and cold-water marine calcifiers. Marine Ecology Progress Series 373:265-273.

Anthony KRN, Diaz-Pulido G, Verlinden N, Tilbrook B, Andersson AJ. 2013. Benthic buffers and boosters of ocean acidification. Biogeosciences Discussions 10: 1831-1865.

Anthony KRN, Kleypas JA, Gattuso JP. 2011. Coral reefs modify their seawater carbon chemistry - implications for impacts of ocean acidification. Global Change Biology 17:3655-3666.

Anthony KRN, Kline DI, Diaz-Pulido G, Dove S, Hoegh-Guldberg O. 2008. Ocean acidification causes bleaching and productivity loss in coral reef builders. Proceedings of the National Academy of Sciences of the United States of America 105:17442-17446.

Borowitzka MA, Larkum AWD. 1976. Calcification in the green-alga Halimeda. 3. Sources of inorganic carbon for photosynthesis and calcification and a model of mechanism of calcification. Journal of Experimental Botany 27:879-893.

Brawley SH, Johnson LE. 1992. Gametogenesis, gametes and zygotes: an ecological perspective on sexual reproduction in the algae. British Phycological Journal 27:233-252.

Camoin GF, Montaggioni LF. 1994. High-energy coralgal-stromatolite frameworks from Holocene reefs (Tahiti, French Polynesia). Sedimentology 41:655-676.

Chisholm JRM. 2003. Primary productivity of reef-building crustose coralline algae. Limnology and Oceanography 48:1376-1387. 
527

528

529

530

531

532

533

534

535

536

537

538

539

540

541

542

543

544

545

546

547

548

549

550

551

552

553

554

555

556

557

558

559

560

561

562

563

564

565

566

567

568

569

570

571

572

573

574
Clifton KE, Clifton LM. 1999. The phenology of sexual reproduction by green algae (Bryopsidales) on Caribbean coral reefs. Journal of Phycology 35:24-34.

Comeau S, Carpenter RC, Edmunds PJ. 2013a. Coral reef calcifiers buffer their response to ocean acidification using both bicarbonate and carbonate. Proceedings of the Royal Society BBiological Sciences 280.

Comeau S, Edmunds PJ, Spindel NB, Carpenter RC. 2013b. The responses of eight coral reef calcifiers to increasing partial pressure of $\mathrm{CO}_{2}$ do not exhibit a tipping point. Limnology and Oceanography 58:10.

Cooper H, Hedges LV, Valentine JC. 1994. The Handbook of Research Synthesis and Metaanalysis. Russell Sage Foundation

Cornwall CE, Hepburn CD, Pritchard D, Currie KI, McGraw CM, Hunter KA, Hurd CL. 2012. Carbon-use strategies in macroalgae: differential responses to lowered $\mathrm{pH}$ and implications for ocean acidification. Journal of Phycology 48:137-144.

Davies PS. 1989. Short-term growth measurements of corals using an accurate buoyant weighing technique. Marine Biology 101:389-395.

Diaz-Pulido G, Gouezo M, Tilbrook B, Dove S, Anthony KRN. 2011. High $\mathrm{CO}_{2}$ enhances the competitive strength of seaweeds over corals. Ecology Letters 14:156-162.

Diaz-Pulido G, Anthony KRN, Kline DI, Dove S, Hoegh-Guldberg O. 2012. Interactions between ocean acidification and warming on the mortality and dissolution of coralline algae. Journal of Phycology 48:32-39.

Dickson AG, Sabine CL, Christian JR. 2007. Guide to best practices for ocean $\mathrm{CO}_{2}$ measurements. PISCES Special Publication 3.

Doney SC, Balch WM, Fabry VJ, Feely RA. 2009. Ocean Acidification: a critical emerging problem for the ocean sciences. Oceanography 22:16-25.

Eberlein T, Van de Waal DB, Rost B. 2013. Differential effects of ocean acidification on carbon acquisition in two bloom-forming dinoflagellate species. Physiolgia plantarum.

Edwards MS, Kim KY. 2010. Diurnal variation in relative photosynthetic performance in giant kelp Macrocystis pyrifera (Phaeophyceae, Laminariales) at different depths as estimated using PAM fluorometry. Aquatic Botany 92:119-128.

Enriquez S, Borowitzka MA. 2010. The use of the fluorescence signal in studies of seagrasses and macroalgae. In Chlorophyll a Fluorescence in Aquatic Sciences: Methods and Applications. Springer: Netherlands, 187-208.

Fabricius KE. 2005. Effects of terrestrial runoff on the ecology of corals and coral reefs: review and synthesis. Marine Pollution Bulletin 50:125-146.

Fabricius KE, Langdon C, Uthicke S, Humphrey C, Noonan S, De'ath G, Okazaki R, Muehllehner N, Glas MS, Lough JM. 2011. Losers and winners in coral reefs acclimatized to elevated carbon dioxide concentrations. Nature Climate Change 1:165169.

Feely RA, Sabine CL, Lee K, Berelson W, Kleypas J, Fabry VJ, Millero FJ. 2004. Impact of anthropogenic $\mathrm{CO}_{2}$ on the $\mathrm{CaCO}_{3}$ system in the oceans. Science 305:362-366.

Frenette JJ, Demers S, Legendre L, Dodson J. 1993. Lack of agreement among models for estimating the photosynthetic parameters. Limnology and Oceanography 38:679-687.

Gao K, Aruga Y, Asada K, Ishihara T, Akano T, Kiyohara M. 1991. Enhanced growth of the red alga Porphyra yezoensis Ueda in high $\mathrm{CO}_{2}$ concentrations. Journal of Applied Phycology 3.

Gao KS, Zheng YQ. 2010. Combined effects of ocean acidification and solar UV radiation on photosynthesis, growth, pigmentation and calcification of the coralline alga Corallina sessilis (Rhodophyta). Global Change Biology 16:2388-2398. 
575

576

577

578

579

580

581

582

583

584

585

586

587

588

589

590

591

592

593

594

595

596

597

598

599

600

601

602

603

604

605

606

607

608

609

610

611

612

613

614

615

616

617

618

619

620

621

622

623
Gattuso J-P, Hansson L. 2011. Ocean acidification: background and history. In: Gattuso JP, Hansson L, eds. Ocean Acidification. Oxford: Oxford University Press.

Gattuso JP, Pichon M, Frankignoulle M. 1995. Biological control of air-sea $\mathrm{CO}_{2}$ fluxes: effect of photosynthetic and calcifying marine organisms and ecosystems. Marine Ecology Progress Series 129:307-312.

Giordano M, Beardall J, Raven JA. 2005. $\mathrm{CO}_{2}$ concentrating mechanisms in algae: mechanisms, environmental modulation, and evolution. Annual Review of Plant Biology 56.

Hall-Spencer JM, Rodolfo-Metalpa R, Martin S, Ransome E, Fine M, Turner SM, Rowley SJ, Tedesco D, Buia MC. 2008. Volcanic carbon dioxide vents show ecosystem effects of ocean acidification. Nature 454:96-99.

Hamilton S, Smith JE, NN Price, Sandin SA. 2014. Quantifying patterns of fish herbivory on Palmyra Atoll (USA), an uninhabited predator-dominated central Pacific coral reef. Marine Ecology Progress Series (in press).

Harley CDG, Anderson KM, Demes KW, Jorve JP, Kordas RL, Coyle TA, Graham MH. 2012. Effects of climate change on global seaweed communities. Journal of Phycology 48:1064-1078.

Haas AF, Nelson CE, Rohwer F, Wegley-Kelly L, Quistad SD, Carlson CA, Leichter JJ, Hatay M, Smith JE. 2013. Influence of coral and algal exudates on microbiallys mediated reef metabolism. PeerJ 1: e108.

Harrington L, Fabricius K, De'Ath G, Negri A. 2004. Recognition and selection of settlement substrata determine post-settlement survival in corals. Ecology 85:3428-3437.

Hoegh-Guldberg O, Mumby PJ, Hooten AJ, Steneck RS, Greenfield P, Gomez E, Harvell CD, Sale PF, Edwards AJ, Caldeira K, Knowlton N, Eakin CM, Iglesias-Prieto R, Muthiga N, Bradbury RH, Dubi A, Hatziolos ME. 2007. Coral reefs under rapid climate change and ocean acidification. Science $\mathbf{3 1 8}$.

Hofmann GE, Smith JE, Johnson KS, Send U, Levin LA, Fiorenza MF, Paytan A, Price NN, Peterson B, Takeshita Y, Matson PG, Crook ED, Kroeker KJ, Gambi MC, Rivest EB, Frieder CA, Yu PC, Martz TR. 2011. High-frequency dynamics of ocean pH: a multiecosystem comparison. PloS ONE: e28983.

Hofmann LC, Straub S, Bischof K. 2013. Elevated $\mathrm{CO}_{2}$ levels affect the activity of nitrate reductase and carbonic anhydrase in the calcifying rhodophyte Corallina officinalis. Journal of Experimental Botany 64:899-908.

Hughes TP. 1994. Catastrophes, phase-shifts, and large-scale degradation of a Caribbean coral reef. Science 265:1547-1551.

Hughes TP, Graham NAJ, Jackson JBC, Mumby PJ, Steneck RS. 2010. Rising to the challenge of sustaining coral reef resilience. Trends in Ecology \& Evolution 25:633-642.

Hurd CL, Hepburn CD, Currie KI, Raven JA, Hunter KA. 2009. Testing the effects of ocean acidification on algal metabolism: considerations for experimental designs. Journal of Phycology 45:1236-1251.

Hurd CL, Cornwall CE, Currie K, Hepburn CD, McGraw CM, Hunter KA, Boyd PW. 2011. Metabolically induced $\mathrm{pH}$ fluctuations by some coastal calcifiers exceed projected $22^{\text {nd }}$ century ocean acidification: a mechanism for differential susceptibility? Global Change Biology 17:3254-3262.

Johnson MD, Carpenter RC. 2012. Ocean acidification and warming decrease calcification in the crustose coralline alga Hydrolithon onkodes and increase susceptibility to grazing.

Journal of Experimental Marine Biology and Ecology 434:94-101.

Johnson MD, Moriarty VW, Carpenter RC. 2014. Acclimatization of the crustose coralline alga Porolithon onkodes to variable $\mathrm{pCO}_{2}$. PLoS ONE: e87678.

Kamenos NA, Burdett HL, Aloisio E, Findlay HS, Martin S, Longbone C, Dunn J, Widdicombe 
624

625

626

627

628

629

630

631

632

633

634

635

636

637

638

639

640

641

642

643

644

645

646

647

648

649

650

651

652

653

654

655

656

657

658

659

660

661

662

663

664

665

666

667

668

669

670
S, Calosi P. 2013. Coralline algal structure is more sensitive to rate, rather than the magnitude, of ocean acidification. Global Change Biology 19:3621-3628.

Kleypas JA, Buddemeier RW, Archer D, Gattuso JP, Langdon C, Opdyke BN. 1999. Geochemical consequences of increased atmospheric carbon dioxide on coral reefs. Science 284:118120.

Knowlton N. 2001. The future of coral reefs. Proceedings of the National Academy of Sciences of the United States of America 98:5419-5425.

Koch M, Bowes G, Ross C, Zhang X-H. 2013. Climate change and ocean acidification effects on seagrasses and marine macroalgae. Global Change Biology 19:103-132.

Kroeker KJ, Kordas RL, Crim RN, Singh GG. 2010. Meta-analysis reveals negative yet variable effects of ocean acidification on marine organisms. Ecology Letters 13:1419-1434.

Kroeker KJ, Kordas RL, Crim R, Hendriks IE, Ramajo L, Singh GS, Duarte CM, Gattuso J-P. 2013. Impacts of ocean acidification on marine organisms: quantifying sensitivities and interaction with warming. Global Change Biology 19:1884-1896.

Kubler JE, Johnston AM, Raven JA. 1999. The effects of reduced and elevated $\mathrm{CO}_{2}$ and $\mathrm{O}_{2}$ on the seaweed Lomentaria articulata. Plant Cell and Environment 22:1303-1310.

Langdon C, Atkinson MJ. 2005. Effect of elevated $\mathrm{pCO}_{2}$ on photosynthesis and calcification of corals and interactions with seasonal change in temperature/irradiance and nutrient enrichment. Journal of Geophysical Research 110:1-16.

Lavigne H, Gattuso JP. 2011. seacarb: seawater carbonate chemistry with R. http://CRAN.Rproject.org/package $=$ seacarb.

Lueker TJ, Dickson AG, Keeling CD. 2000. Ocean $\mathrm{pCO}_{2}$ calculated from dissolved inorganic carbon, alkalinity, and equations for $\mathrm{K}-1$ and $\mathrm{K}-2$ : validation based on laboratory measurements of $\mathrm{CO}_{2}$ in gas and seawater at equilibrium. Marine Chemistry 70:105-119.

Liu Y, Xu J, Gao K. 2012. $\mathrm{CO}_{2}$ driven seawater acidification increases photochemical stress in a green alga. Phycologia 51:562-566.

Mantyka CS, Bellwood DR. 2007. Macroalgal grazing selectivity among herbivorous coral reef fishes. Marine Ecology Progress Series 352:177-185.

Martin S, Gattuso JP. 2009. Response of Mediterranean coralline algae to ocean acidification and elevated temperature. Global Change Biology 15:2089-2100.

Martin S, Cohu S, Vignot C, Zimmerman G, Gattuso JP. 2013. One-year experiment on the physiological response of the Mediterranean crustose coralline alga, Lithophyllum cabiochae, to elevated $\mathrm{pCO}_{2}$ and temperature. Ecology and Evolution DOI 10.1002/ece3.475.

McCook LJ, Jompa J, Diaz-Pulido G. 2001. Competition between corals and algae on coral reefs: a review of evidence and mechanisms. Coral Reefs 19:400-417.

Meinshausen M, Smith SJ, Calvin K, Daniel JS, Kainuma MLT, Lamarque JF, Matsumoto K, Montzka SA, Raper SCB, Riahi K, Thomson A, Velders GJM, van Vuuren DPP. 2011. The RCP greenhouse gas concentrations and their extensions from 1765 to 2300. Climatic Change 109:213-241.

Milliman JD, Gastner M, Muller J. 1971. Utilization of magnesium in coralline algae. Geological Society of America Bulletin 82:573-580.

Milliman JD, Troy PJ, Balch WM, Adams AK, Li YC, Mackenzie FT. 1999. Biologically mediated dissolution of calcium carbonate above the chemical lysocline? Deep Sea Research Part I: Oceanographic Research Papers 46:1653-1669.

Moberg F, Folke C. 1999. Ecological goods and services of coral reef ecosystems. Ecological Economics 29:215-233. 
671

672

673

674

675

676

677

678

679

680

681

682

683

684

685

686

687

688

689

690

691

692

693

694

695

696

697

698

699

700

701

702

703

704

705

706

707

708

709

710

711

712

713

714

715

716

717

718

719
Morse JW, Andersson AJ, Mackenzie FT. 2006. Initial responses of carbonate-rich shelf sediments to rising atmospheric $\mathrm{pCO}_{2}$ and "ocean acidification": Role of high Mgcalcites. Geochimica Et Cosmochimica Acta 70:5814-5830.

Nash MC, Opdyke BN, Troitzsch U, Russell BD, Adey WH, Kato A, Diaz-Pulido G, Brent C, Gardner M, Prichard J, Kline DI. 2012. Dolomite-rich coralline algae in reefs resist dissolution in acidified conditions. Nature Climate Change 3:268-272.

Nelson CE, Goldberg SJ, Kelly LW, Haas AF, Smith JE, Rohwer F, Carlson CA. 2013. Coral and macroalgal exudates vary in neutral sugar composition and differentially enrich reef bacterioplankton lineages. The ISME Journal 7:962-979.

Nugues MM, Smith GW, Hooidonk RJ, Seabra MI, Bak RPM. 2004. Algal contact as a trigger for coral disease. Ecology Letters 7:919-923.

Ohde S, van Woesik R. 1999. Carbon dioxide flux and metabolic processes of a coral reef, Okinawa. Bulletin of Marine Science 65:559-576.

Orr JC, Fabry VJ, Aumont O, Bopp L, Doney SC, Feely RA, Gnanadesikan A, Gruber N, Ishida A, Joos F, Key RM, Lindsay K, Maier-Reimer E, Matear R, Monfray P, Mouchet A, Najjar RG, Plattner GK, Rodgers KB, Sabine CL, Sarmiento JL, Schlitzer R, Slater RD, Totterdell IJ, Weirig MF, Yamanaka Y, Yool A. 2005. Anthropogenic ocean acidification over the twenty-first century and its impact on calcifying organisms. Nature 437:681-686.

Palacios SL, Zimmerman RC. 2007. Response of eelgrass Zostera marina to $\mathrm{CO}_{2}$ enrichment: possible impacts of climate change and potential for remediation of coastal habitats. Marine Ecology Progress Series 344:1-13.

Pierrot D, Lewis E, Wallace DWR. 2006. MS Excel program developed by $\mathrm{CO}_{2}$ system calculations, Carbon dioxide Information Center, Oak Ridge National Laboratory, U.S. Department of Energy.

Platt T, Gallegos CL, Harrison WG. 1980. Photoinhibition of photosynthesis in natural assemblages of marine phytoplankton. Journal of Marine Research 38:687-701.

Porzio L, Buia MC, Hall-Spencer JM. 2011. Effects of ocean acidification on macroalgal communities. Journal of Experimental Marine Biology and Ecology 400:278-287.

Price NN. 2010. Habitat selection, facilitation, and biotic settlement cues affect distribution and performance of coral recruits in French Polynesia. Oecologia 163:747-758.

Price NN, Hamilton SL, Tootell JS, Smith JE. 2011. Species-specific consequences of ocean acidification for the calcareous tropical green algae Halimeda. Marine Ecology Progress Series 440:67-78.

Ragazzola F, Foster LC, Form A, Anderson PSL, Hansteen TH, Fietzke J. 2012. Ocean acidification weakens the structural integrity of coralline algae. Global Change Biology 18:2804-2812.

Rasher DB, Engel S, Bonito V, Fraser GJ, Montoya JP, Hay ME. 2012. Effects of herbivory, nutrients, and reef protection on algal proliferation and coral growth on a tropical reef. Oecologia 169:187-198.

Raven JA. 1970. Exogenous inorganic carbon sources in plant photosynthesis. Biological Reviews of the Cambridge Philosophical Society 45:167-220.

Raven JA, Giordano M, Beardall J, Maberly SC. 2011. Algal and aquatic plant carbon concentrating mechanisms in relation to environmental change. Photosynthesis Research 109:281-296.

Rees SA, Opdyke BN, Wilson PA, Henstock TJ. 2007. Significance of Halimeda bioherms to the global carbonate budget based on a geological sediment budget for the Northern Great Barrier Reef, Australia. Coral Reefs 26.

Riebesell U, Burkhardt S, Pahlow M, Wischmeyer A, Wolf-Gladrow D. 1997. Algal responses to increasing $\mathrm{CO}_{2}$ concentrations. Phycologia 36:93-93. 
720

721

722

723

724

725

726

727

728

729

730

731

732

733

734

735

736

737

738

739

740

741

742

743

744

745

746

747

748

749

750

751

752

753

754

755

756

757

758

759

760

761

762

763
Ries JB, Cohen AL, McCorkle DC. 2009. Marine calcifiers exhibit mixed responses to $\mathrm{CO}_{2}$ induced ocean acidification. Geology 37:1131-1134.

Sandin SA, Smith JE, DeMartini EE, Dinsdale EA, Donner SD, Friedlander AM, Konotchick T, Malay M, Maragos JE, Obura D, Pantos O, Paulay G, Richie M, Rohwer F, Schroeder RE, Walsh S, Jackson JBC, Knowlton N, Sala E. 2008. Baselines and degradation of coral reefs in the Northern Line Islands. PLoS ONE 3:e1548.

Sarker MY, Bartsch I, Olischlager M, Gutow L, Wiencke C. 2013. Combined effects of $\mathrm{CO}_{2}$, temperature, irradiance, and time on the physiological performance of Chondrus crispus (Rhodophyta) Botanica Marina 56:63-74.

Saroussi S, Beer S. 2007. Alpha and quantum yield of aquatic plants derived from PAM fluorometry: uses and misuses. Aquatic Botany 86:89-92.

Semesi IS, Kangwe J, Bjork M. 2009. Alterations in seawater $\mathrm{pH}$ and $\mathrm{CO}_{2}$ affect calcification and photosynthesis in the tropical coralline alga, Hydrolithon sp (Rhodophyta). Estuarine Coastal and Shelf Science 84:337-341.

Sinutok S, Hill R, Doblin MA, Wuhrer R, Ralph PJ. 2011. Warmer more acidic conditions cause decreased productivity and calcification in subtropical coral reef sediment-dwelling calcifiers. Limnology and Oceanography 56:1200-1212.

Sinutok S, Hill R, Doblin MA, Kuhl M, Ralph PJ. 2012. Microenvironmental changes support evidence of photosynthesis and calcification inhibition in Halimeda under ocean acidification and warming. Coral Reefs 31:1201-1213.

Smith JE, Hunter CL, Smith CM. 2002. Distribution and reproductive characteristics of nonindigenous and invasive marine algae in the Hawaiian Islands. Pacific Sciences 56:299-315.

Smith JE, Smith CM, Vroom PS, Beach KL, Miller S. 2004. Nutrient and growth dynamics of Halimeda tuna on Conch Reef, Florida Keys: Possible influence of internal tides on nutrient status and physiology. Limnology and Oceanography 49:1923-1936.

Smith JE, Shaw M, Edwards RA, Obura D, Pantos O, Sala E, Sandin SA, Smriga S, Hatay M, Rohwer FL. 2006. Indirect effects of algae on coral: algae-mediated, microbe-induced coral mortality. Ecology Letters 9:835-845.

Smith JE, Price NN, Nelson CE, and Haas AF. 2013. Coupled changes in dissolved oxygen and $\mathrm{pH}$ caused by metabolism of benthic coral reef organisms. Marine Biology 160:23472447.

Tribollet A, Payri C. 2001. Bioerosion of the coralline alga Hydrolithon onkodes by microborers in the coral reefs of Moorea, French Polynesia. Oceanologica Acta 24:329-342111.

Valiela I. 1984. Marine Ecological Processes. Springer-Verlag, New York.

Williams GJ, Smith JE, Conklin EJ, Gove JM, Sala E, Sandin SA. 2013. Benthic communities at two remote Pacific coral reefs: effects of reef habitat, depth, and wave energy gradients on spatial patterns. PeerJ 1: e81.

Williamson C. 2010. Salinity and temperature effects on release of sexual products and other organic matter by coral reef-associated green algae of the genus Caulerpa. D. Phil. Thesis, Ludwig-Maximilians University.

Yildiz G, Hofmann LC, Bischof K, Dere S. 2013. Ultraviolet radiation modulates the physiological responses of the calcified rhodophyte Corallina officinalis to elevated $\mathrm{CO}_{2}$. Botanica Marina 56:161-168. 


\section{Figure 1}

Growth response of fleshy and calcareous algae to treatment conditions.

The eleven species of algae exposed to $\mathrm{CO}_{2}$ enrichment experiments on Palmyra Atoll. Algae were separated by functional group. The species of fleshy macroalgae included: A. Acanthophora spicifera, B. Avrainvillea amadelpha, C. Caulerpa serrulata, D. Dictyota bartayresiana, E. Hypnea pannosa. The upright calcareous algae included: F. Dichotomaria marginata, G. Galaxaura rugosa, H. Halimeda taenicola, I. Halimeda opuntia, and the CCA included: J. Lithophyllum sp., K. Lithophyllum prototypum. L. The mean ( $\pm \mathrm{SE})$ change in either fleshy or calcareous biomass (highlighted in gray) following exposure to either presentday ambient air controls (open circles) or predicted OA treatments (closed circles). Fleshy macroalgae are shown in brown, upright calcareous algae in green, and CCA in red. Species tested in multiple experiments were pooled across years. * Indicates a significant difference between treatments as determined by independent t-tests (results reported in Table 2). 
Fleshy algae

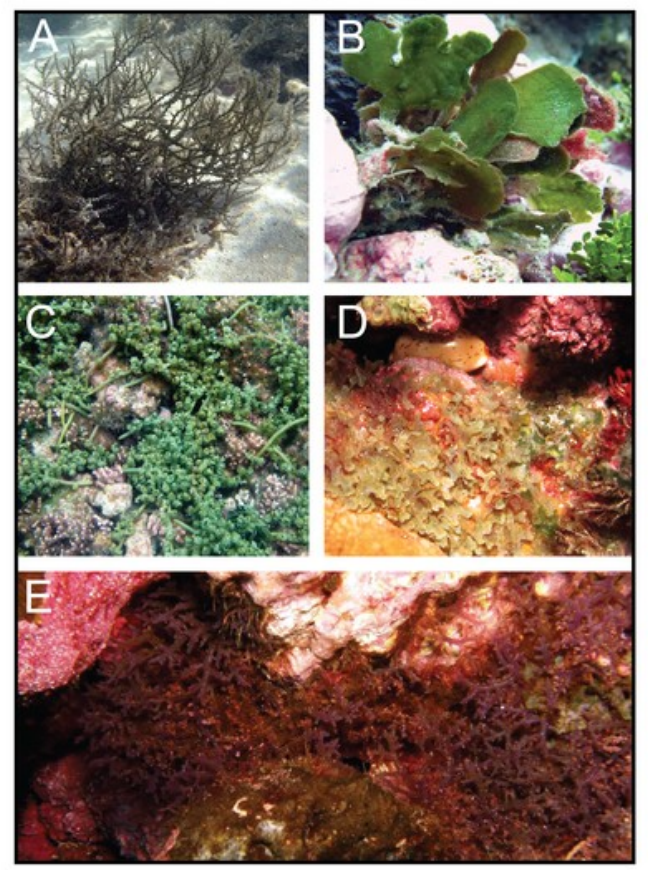

Calcareous algae
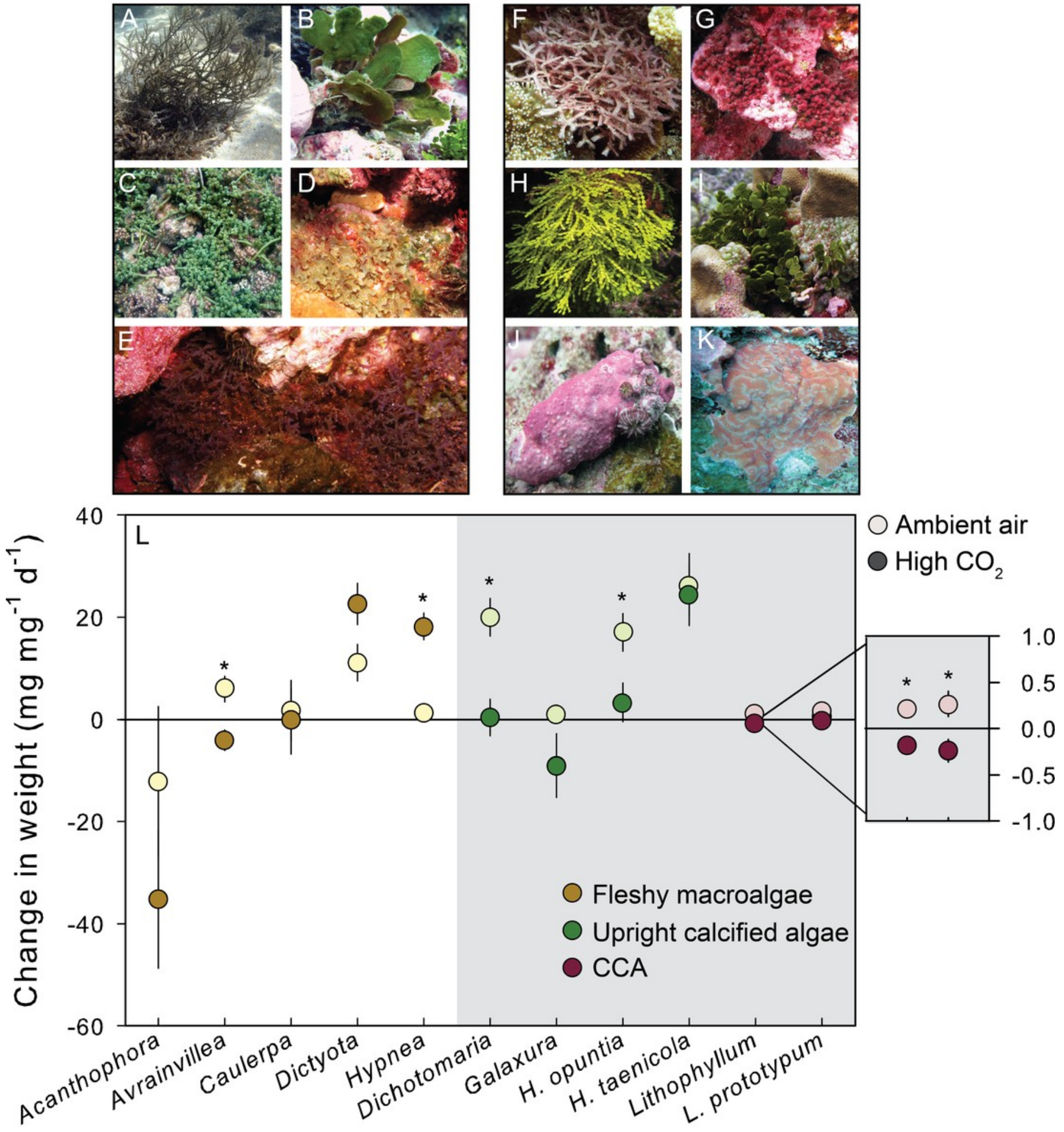

Species 


\section{Figure 2}

Species-specific growth response to treatment conditions.

The mean $( \pm \mathrm{SE})$ change in either fleshy or calcareous biomass following exposure to either present-day ambient air controls (open circles) or predicted OA treatments (closed circles) for species tested in multiple experiments. The dashed line is positioned at zero to indicate relative growth or loss of tissue for a) Halimeda opuntia, b) Halimeda taenicola, c) Lithophyllum sp., and d) Caulerpa serrulata. Fleshy macroalgae are shown in brown, upright calcareous algae in green, and CCA in red. * Indicates a significant difference between treatments as determined by independent t-tests (results reported in Table 3).

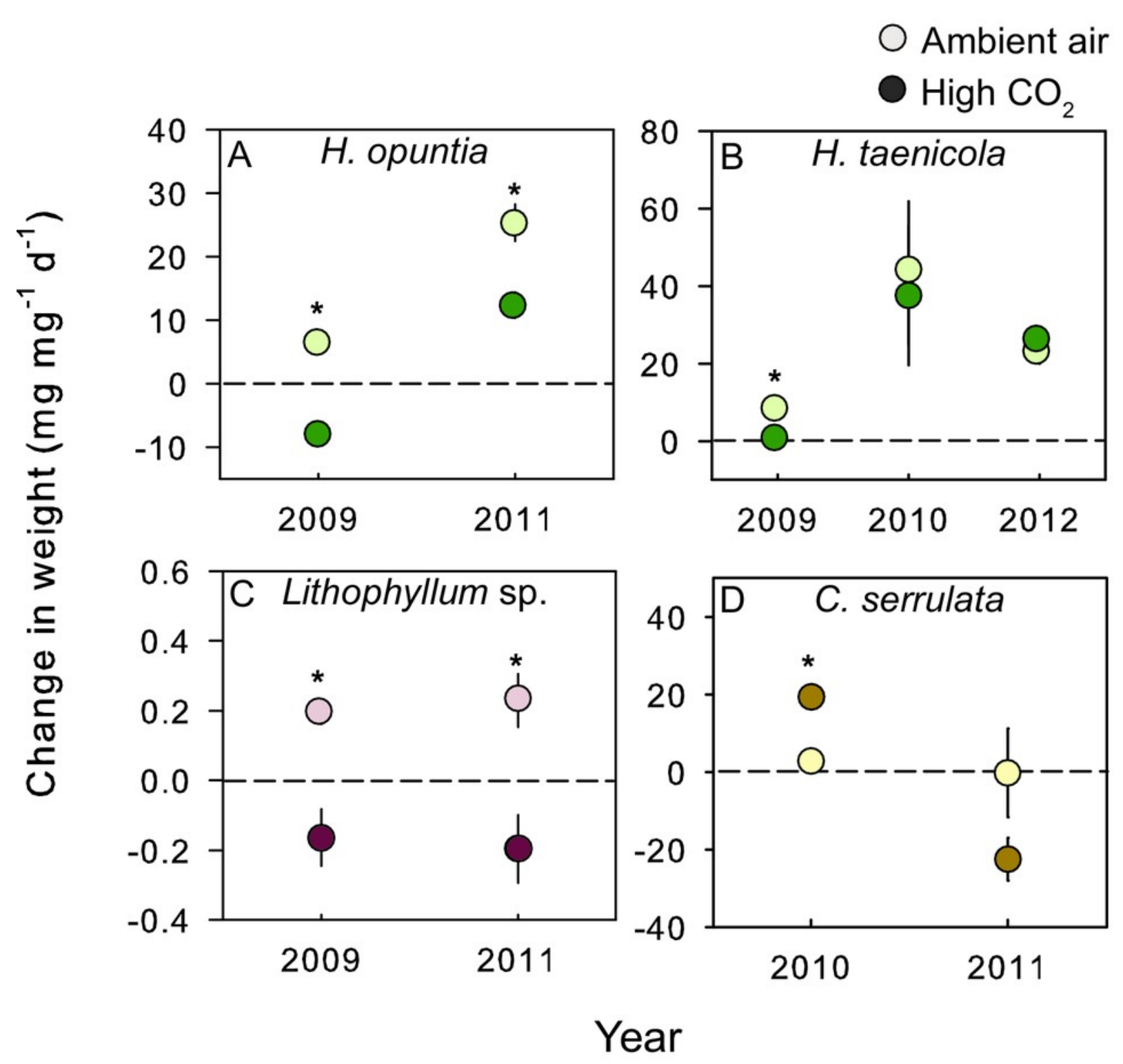




\section{Figure 3}

Photosynthetic response of fleshy and calcareous algae to treatment conditions.

The mean ( \pm SE) photosynthetic parameters from RLCs following exposure to either presentday ambient air controls (open circles) or predicted OA treatments (closed circles). Species tested in multiple experiments were pooled across years. RLCs were measured fluorometrically with a pulse amplitude modulated fluorometer (PAM), and fit to the model of Platt et al. (1980). From the model we derived a) maximum photosynthetic performance $\left.\left(r E T R_{\text {Max }}\right), b\right)$ photosynthetic efficiency $(\alpha)$, and c) photoinhibition ( $\left.\beta\right)$. Parameters from replicate RLCs were averaged for each individual. Fleshy macroalgae are shown in brown, upright calcareous algae in green, and CCA in red. * Indicates a significant difference between treatments as determined by independent t-tests (results reported in Table 2). 


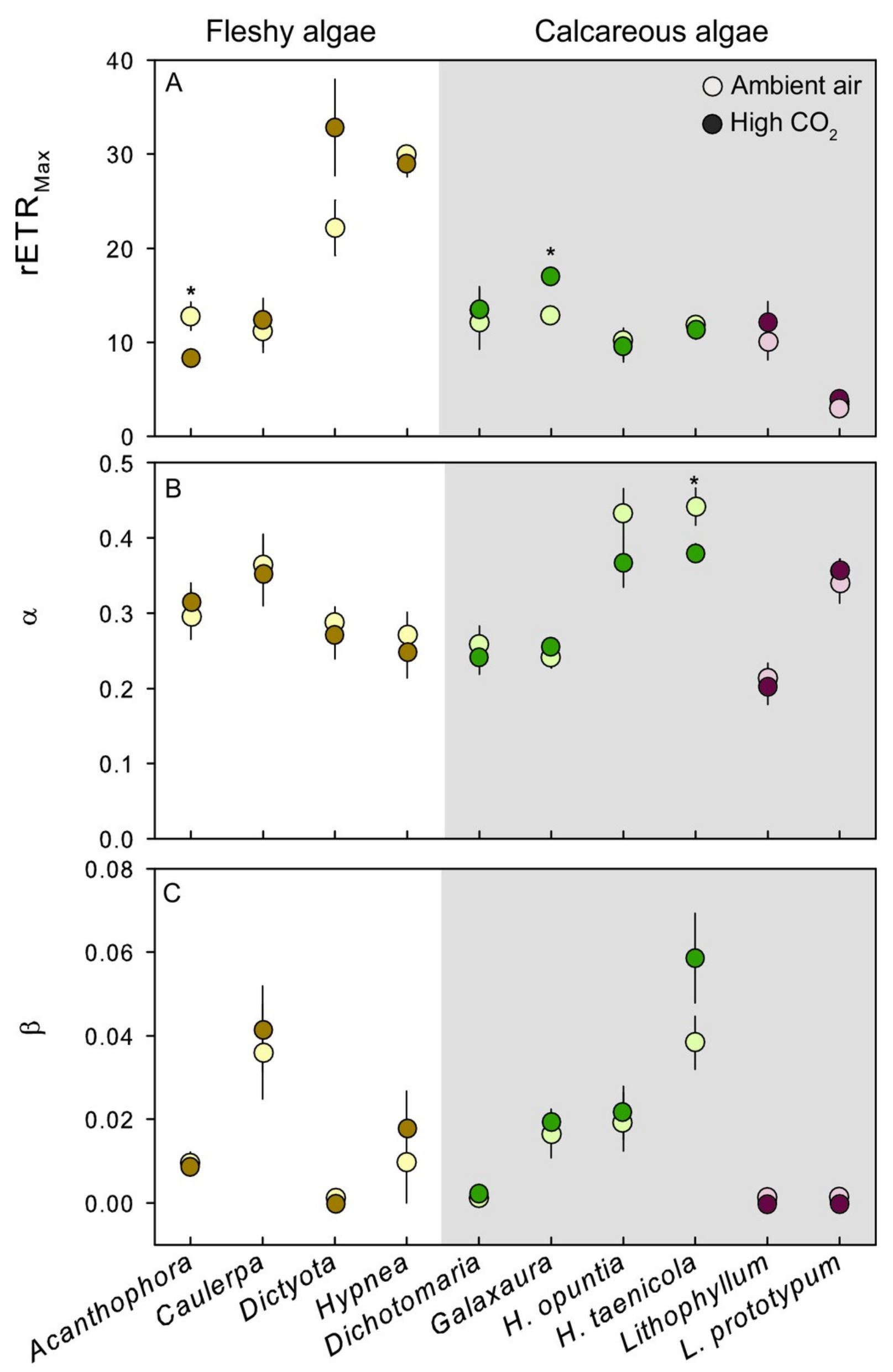




\section{Figure 4}

Functional group responses to $O A$.

Mean $( \pm 95 \% \mathrm{Cl})$ effect sizes were calculated to explore the cumulative effects of $O A$ on algae categorized into functional groups (fleshy macroalgae, upright calcareous algae, and crustose coralline algae (CCA). Species that reproduced during experiments were not included in this analysis. The dashed line is positioned at zero to indicate a relative increase or decrease following exposure to $\mathrm{OA}$ conditions for a) change in weight, b) maximum photosynthetic capacity $\left.\left(\mathrm{rETR}_{\mathrm{Max}}\right), \mathrm{c}\right)$ photosynthetic efficiency $(\alpha)$, and c) photoinhibition ( $\left.\beta\right)$.

Fleshy macroalgae are shown in brown circles, upright calcareous algae in green, and CCA in red. * Indicates an effect size different than zero as determined by meta-analysis (results reported in Table 4). 

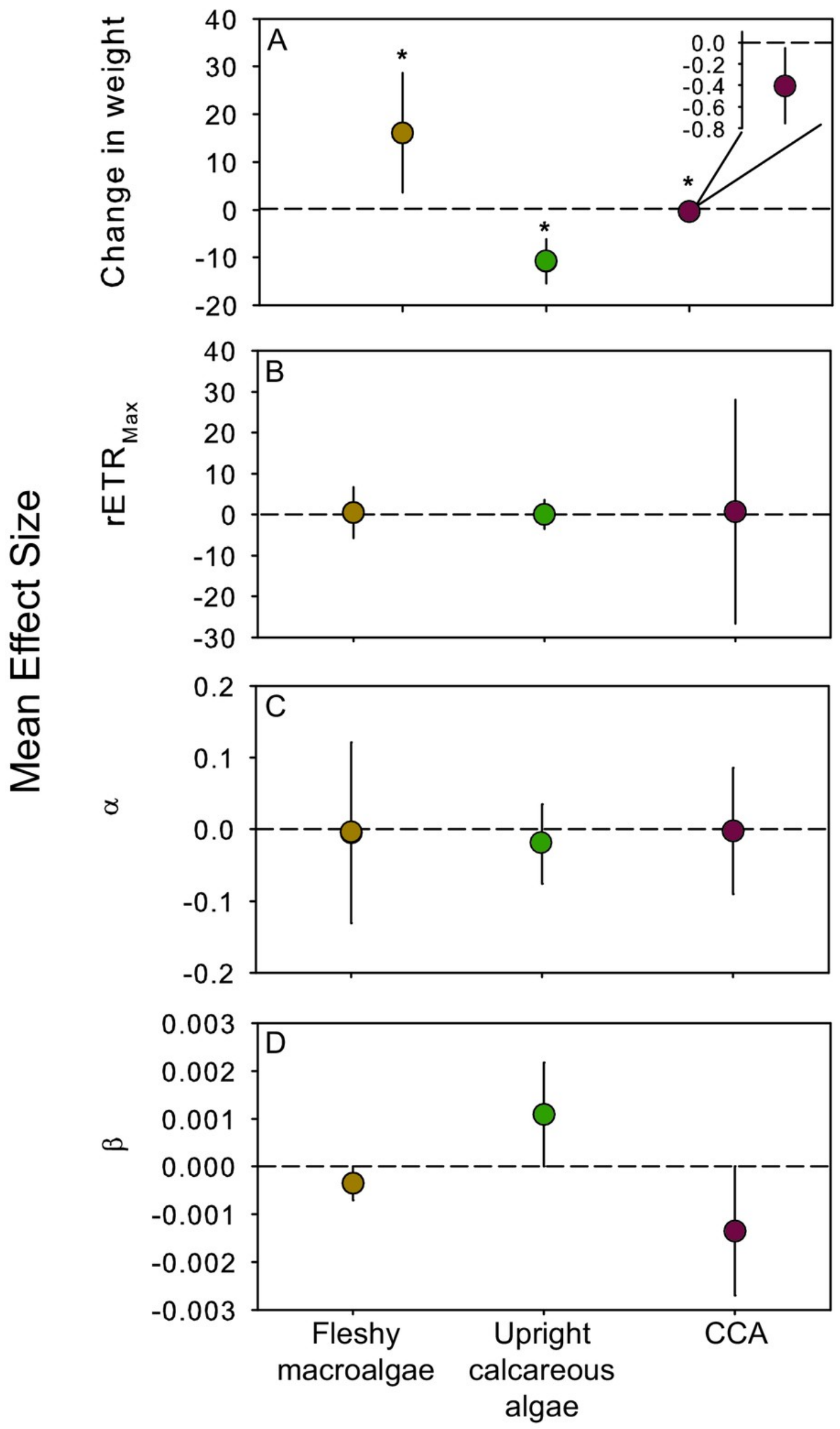

Functional Group 


\section{Table 1 (on next page)}

Measured $\mathrm{pH}$ and dissolved oxygen of OA experiments on Palmyra Atoll.

The mean $( \pm \mathrm{SE})$ measured $\mathrm{pH}_{\mathrm{SW}}$ and dissolved oxygen conditions for $\mathrm{CO}_{2}$ enrichment experiments conducted on Palmyra Atoll from 2009-2012. Measurements were conducted at the same time of day ( 2000) for the duration of the experiment in empty control (no biological material), ambient air, and high $\mathrm{pCO}_{2}$ treatments. Daily means were calculated within a species $(n=4,2009 ; n=6,2010 ; n=5,2011 ; n=10,2012)$, and then averaged across days (14 days, 2009; 9 days, 2010; 17 days, 2011; 15 days, 2012). DO: dissolved oxygen, $\mathrm{pH}_{\mathrm{SW}}$ : $\mathrm{pH}$ seawater scale 
Table 1. Measured pH and dissolved oxygen of OA experiments on Palmyra Atoll.

\begin{tabular}{|c|c|c|c|c|}
\hline Treatment & Species & Temperature $\left({ }^{\circ} \mathrm{C}\right)$ & $\mathrm{DO}\left(\mathrm{mg} \mathrm{L}^{-1}\right)$ & $\mathrm{pH}_{\mathrm{SW}}$ \\
\hline \multicolumn{5}{|c|}{2009 Experiments } \\
\hline \multirow[t]{5}{*}{ Ambient air } & Control & $29.31 \pm 0.07$ & $4.95 \pm 0.13$ & $8.08 \pm 0.02$ \\
\hline & H. opuntia & $29.26 \pm 0.08$ & $4.57 \pm 0.16$ & $8.03 \pm 0.04$ \\
\hline & H. taenicola & $29.29 \pm 0.08$ & $4.73 \pm 0.12$ & $7.99 \pm 0.03$ \\
\hline & Lithophyllum sp. & $29.43 \pm 0.03$ & $5.17 \pm 0.11$ & $8.05 \pm 0.01$ \\
\hline & L. prototypum & $29.38 \pm 0.02$ & $5.16 \pm 0.16$ & $8.04 \pm 0.02$ \\
\hline \multirow[t]{5}{*}{ High $\mathrm{pCO}_{2}$} & Control & $29.33 \pm 0.06$ & $4.66 \pm 0.26$ & $7.68 \pm 0.04$ \\
\hline & H. opuntia & $29.23 \pm 0.08$ & $4.16 \pm 0.21$ & $7.63 \pm 0.02$ \\
\hline & H. taenicola & $29.25 \pm 0.07$ & $4.38 \pm 0.19$ & $7.62 \pm 0.02$ \\
\hline & Lithophyllum sp. & $29.41 \pm 0.03$ & $5.47 \pm 0.10$ & $7.68 \pm 0.03$ \\
\hline & L. prototypum & $29.38 \pm 0.02$ & $4.71 \pm 0.21$ & $7.65 \pm 0.02$ \\
\hline
\end{tabular}

2010 Experiments

Ambient air Control

A. spicifera

C. serrulata

G. rugosa

H. taenicola

High $\mathrm{pCO}_{2} \quad$ Control

A. spicifera

C. serrulata

G. rugosa

H. taenicola
$29.25 \pm 0.15$

$29.22 \pm 0.07$

$28.95 \pm 0.04$

$29.25 \pm 0.02$

$29.36 \pm 0.05$

$29.25 \pm 0.05$

$29.10 \pm 0.05$

$28.91 \pm 0.03$

$29.21 \pm 0.07$

$29.34 \pm 0.06$
$4.85 \pm 0.05$

$4.86 \pm 0.06$

$4.79 \pm 0.13$

$4.92 \pm 0.06$

$4.78 \pm 0.07$

$4.70 \pm 0.30$

$4.57 \pm 0.18$

$4.30 \pm 0.17$

$4.50 \pm 0.28$

$4.69 \pm 0.13$

$28.46 \pm 0.21$

$28.34 \pm 0.06$

$28.35 \pm 0.01$

$28.26 \pm 0.18$

$28.44 \pm 0.10$

$28.87 \pm 0.04$

$28.92 \pm 0.14$

High $\mathrm{pCO}_{2}$
Control

D. bartayresiana

H. pannosa

D. marginata

H. opuntia

Lithophyllum sp.

Control

C. serrulata

D. bartayresiana

H. pannosa

D. marginata

H. opuntia

Lithophyllum sp.
$28.30 \pm 0.16$

$28.86 \pm 0.09$

$28.39 \pm 0.01$

$28.38 \pm 0.04$

$28.87 \pm 0.21$

$28.87 \pm 0.09$

$28.46 \pm 0.08$
$7.98 \pm 0.08$

$7.93 \pm 0.03$

$7.97 \pm 0.04$

$7.68 \pm 0.04$

$7.86 \pm 0.06$

$8.12 \pm 0.04$

$7.87 \pm 0.05$

$8.02 \pm 0.08$

$7.85 \pm 0.02$

$7.93 \pm 0.03$

$7.68 \pm 0.22$

$7.87 \pm 0.05$

$8.39 \pm 0.09$

$7.82 \pm 0.07$
$8.06 \pm 0.05$

$8.08 \pm 0.04$

$8.09 \pm 0.02$

$8.09 \pm 0.02$

$7.98 \pm 0.04$

$7.79 \pm 0.13$

$7.88 \pm 0.05$

$7.77 \pm 0.06$

$7.87 \pm 0.06$

$7.77 \pm 0.11$

\section{Experiments}

Ambient air Control

$28.61 \pm 0.10$

$7.81 \pm 0.02$

$7.99 \pm 0.06$

$8.00 \pm 0.02$

$8.04 \pm 0.02$

$7.98 \pm 0.11$

$8.05 \pm 0.01$

$7.97 \pm 0.03$

$8.03 \pm 0.06$

$7.76 \pm 0.06$

$7.66 \pm 0.03$

$7.76 \pm 0.02$

$7.86 \pm 0.04$

$7.80 \pm 0.03$

$7.69 \pm 0.03$

$7.74 \pm 0.06$

$8.11 \pm 0.03$

$8.02 \pm 0.01$ 


\begin{tabular}{lllll} 
& H. taenicola & $28.76 \pm 0.08$ & $7.90 \pm 0.05$ & $8.01 \pm 0.03$ \\
High $\mathrm{pCO}_{2}$ & Control & $28.71 \pm 0.07$ & $7.81 \pm 0.03$ & $7.85 \pm 0.08$ \\
& A. amadelpha & $28.68 \pm 0.07$ & $7.87 \pm 0.08$ & $7.75 \pm 0.05$ \\
& H. taenicola & $28.72 \pm 0.18$ & $7.98 \pm 0.20$ & $7.73 \pm 0.06$ \\
\hline
\end{tabular}




\section{Table 2 (on next page)}

Results of pooled growth and photosynthetic parameters in response to treatment conditions.

The results of independent t-tests to analyze the effect of $\mathrm{CO}_{2}$ enrichment on response variables for each species. Responses of species used in multiple experiments (different years) were pooled and averaged across years by treatment to calculate an overall mean for each species. $\mathrm{CO}_{2}$ treatment was treated as a fixed, independent factor. Degrees of freedom (df) are the same for all photosynthetic parameters. Each experimental replicate (n) consisted of one aquarium containing one algal individual. Statistically significant differences $(p<0.05)$ are emphasized in bold. 
Table 2. Results of growth and photosynthetic parameters in response to treatment conditions.

\begin{tabular}{|c|c|c|c|c|c|c|c|c|c|c|}
\hline \multirow{2}{*}{ 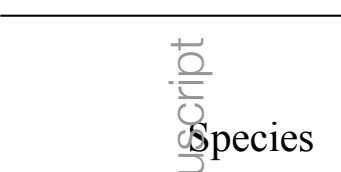 } & \multicolumn{3}{|c|}{ Growth } & \multicolumn{3}{|c|}{$\mathrm{rETR}_{\mathrm{Max}}$} & \multicolumn{2}{|c|}{$\alpha$} & \multicolumn{2}{|c|}{$\beta$} \\
\hline & $\mathrm{df}$ & $\mathrm{t}$ & $\mathrm{p}$ & $\mathrm{df}$ & $\mathrm{t}$ & $\mathrm{p}$ & $\mathrm{t}$ & $\mathrm{p}$ & $\mathrm{t}$ & $\mathrm{p}$ \\
\hline \multicolumn{11}{|l|}{ Fleshy mi্gcroalgae } \\
\hline A. spiciferen & 10 & 1.15 & 0.275 & 9 & 2.55 & 0.031 & 0.341 & 0.741 & 0.088 & 0.932 \\
\hline A. amade丞ha & 18 & 3.12 & 0.006 & & & & & & & \\
\hline C. serrulata & 0.066 & 0.948 & & 19 & 0.282 & 0.781 & 0.350 & 0.730 & 0.356 & 0.726 \\
\hline D. bartavesiana & 2.13 & 0.066 & & 8 & 1.55 & 0.159 & 0.274 & 0.791 & 1.14 & 0.292 \\
\hline H. panno $a$ & 4.90 & 0.004 & & 5 & 0.186 & 0.556 & 0.602 & 0.60 & 0.624 & 0.560 \\
\hline
\end{tabular}

Upright calcareous algae

$\begin{array}{lccccccccc}\text { D. marginata } & 3.83 & \mathbf{0 . 0 0 5} & 8 & 0.440 & 0.83 & 0.092 & 0.929 & 0.823 & 0.434 \\ \text { G. rugosa } & 1.63 & 0.134 & 10 & 4.10 & \mathbf{0 . 0 0 2} & 1.71 & 0.118 & 0.760 & 0.465 \\ \text { H. opuntia } & 2.59 & \mathbf{0 . 0 2 0} & 16 & 0.046 & 0.964 & 1.43 & 0.171 & 0.223 & 0.827 \\ \text { H. taenicola } & 0.21 & 0.832 & 18 & 0.193 & 0.849 & 2.23 & \mathbf{0 . 0 3 9} & 1.62 & 0.123\end{array}$

Crustose coralline algae

$\begin{array}{llllllllll}\text { Lithophyllum sp. } & 5.28 & <\mathbf{0 . 0 0 0 1} & 16 & 0.582 & 0.569 & 0.280 & 0.783 & 1.0 & 0.332\end{array}$




\begin{tabular}{llllllll}
\hline L. prototypum & 2.79 & $\mathbf{0 . 0 3 2}$ & 6 & 0.357 & 0.733 & 0.404 & 0.700 \\
\hline
\end{tabular}

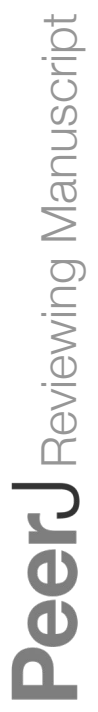




\section{Table 3 (on next page)}

Results of growth/calcification by species and year.

The mean growth and calcification rates of species tested in multiple experiments were examined using independent t-tests for each species by year; $\mathrm{CO}_{2}$ treatment was treated as a fixed, independent factor. Each experimental replicate (n) consisted of one aquarium containing one algal individual. Statistically significant differences $(p<0.05)$ are emphasized in bold. 
Table 3. Results of growth/calcification by species and year.

\begin{tabular}{|c|c|c|c|c|c|}
\hline \multirow[b]{2}{*}{ Species } & & \multirow[b]{2}{*}{ Year } & \multicolumn{3}{|c|}{ Growth } \\
\hline & & & df & $\mathrm{t}$ & $\mathrm{p}$ \\
\hline \multicolumn{6}{|c|}{ Fleshy macroalgae } \\
\hline \multirow[t]{2}{*}{ C. serrulata } & 2010 & 10 & 4.28 & 0.002 & \\
\hline & 2011 & 8 & 1.75 & 0.119 & \\
\hline \multicolumn{5}{|c|}{ Upright calcareous algae } & \\
\hline \multirow[t]{2}{*}{ H. opuntia } & 2009 & 6 & 7.32 & 0.0003 & \\
\hline & 2011 & 8 & 3.62 & 0.007 & \\
\hline \multirow[t]{3}{*}{ H. taenicola } & 2009 & 6 & 5.93 & 0.001 & \\
\hline & 2010 & 10 & 0.224 & 0.827 & \\
\hline & 2012 & 18 & 0.612 & 0.548 & \\
\hline \multicolumn{5}{|c|}{ Crustose coralline algae } & \\
\hline \multirow[t]{2}{*}{ Lithophyllum sp. } & 2009 & 6 & 4.10 & 0.006 & \\
\hline & 2011 & 8 & 3.43 & 0.009 & \\
\hline
\end{tabular}




\section{Table 4 (on next page)}

Meta-analysis results.

Heterogeneity $\left(Q_{T}\right)$ in overall analyses and results from a random effects model of standardized mean differences for response variables pooled by functional group: fleshy macroalgae, upright calcareous algae, or crustose coralline algae (CCA). Statistically significant values $(p<0.05)$ are emphasized in bold. $r E T R_{\text {Max }}$ : maximum relative electron transport rate $\left(\mu \mathrm{M}\right.$ photon $\left.\mathrm{m}^{-2} \mathrm{sec}^{-1}\right) ; \alpha$ : photosynthetic efficiency or initial slope of the rapid light curve ( $\mu \mathrm{M}$ electrons $\mu \mathrm{M}$ photons $\left.{ }^{-1}\right) ; \beta$ : photoinhibition ( $\mu \mathrm{M}$ electrons $\mu \mathrm{M}$ photons ${ }^{-1}$ ) 
Table 4. Meta-analysis results

\begin{tabular}{|c|c|c|c|c|c|c|c|}
\hline Response & $\mathrm{df}$ & $\mathrm{Q}_{\mathrm{T}}$ & $\mathrm{p}$ & $\mathrm{k}$ & Mean Effect Size & Z & $\mathrm{p}$ \\
\hline \multicolumn{8}{|l|}{ Fieshy macroalgae } \\
\hline Growth & 1 & 0.07 & $>0.05$ & 3 & $16.1 \pm 12.5$ & 2.11 & \multirow{3}{*}{0.017} \\
\hline$\vec{c}$ & 9 & & & & & & \\
\hline 15R $\mathrm{Tax}_{\mathrm{M}}$ & 1 & 0.18 & $>0.05$ & 3 & $0.454 \pm 6.19$ & 0.144 & \\
\hline ర్ర & 2 & & & & & & \multirow[t]{2}{*}{0.886} \\
\hline$\alpha \sum_{\Sigma}$ & 1 & 0.07 & $>0.05$ & 3 & $-0.005 \pm 0.13$ & 0.073 & \\
\hline (1) & 2 & & & & & & \multirow[t]{2}{*}{0.471} \\
\hline$\beta_{0}$ & 1 & 0.16 & $>0.05$ & 3 & $-0.0004 \pm 0.0009$ & 0.632 & \\
\hline$\simeq$ & 2 & & & & & & 0.2248 \\
\hline pright calcareou & & & & & & & \\
\hline rowth & 4 & 2.04 & $>0.05$ & 7 & $-10.8 \pm 4.7$ & 3.80 & 0.0001 \\
\hline $\mathrm{TR}_{\mathrm{Max}}$ & 4 & 1.62 & $>0.05$ & 6 & $0.031 \pm 3.56$ & 0.017 & 0.987 \\
\hline 然 & 4 & 0.72 & $>0.05$ & 6 & $-0.020 \pm 0.06$ & 0.722 & 0.470 \\
\hline B & 4 & 0.60 & $>0.05$ & 6 & $0.001 \pm 0.01$ & 0.756 & 0.4333 \\
\hline \multicolumn{8}{|c|}{ Crustose coralline algae } \\
\hline Growth & 6 & 0.08 & $>0.05$ & 3 & $-0.405 \pm 0.35$ & 1.90 & 0.029 \\
\hline $\mathrm{rETR}_{\mathrm{Max}}$ & 6 & 0 & $>0.05$ & 3 & $0.693 \pm 27.4$ & 0.339 & 0.735 \\
\hline$\alpha$ & 6 & 0.05 & $>0.05$ & 3 & $-0.002 \pm 0.09$ & 0.053 & 0.941 \\
\hline$\beta$ & 6 & 0 & $>0.05$ & 3 & $-0.001 \pm 0.004$ & 0.169 & 0.2637 \\
\hline
\end{tabular}




\section{Table 5 (on next page)}

OA effects on tropical benthic macroalgae.

A summary of findings to date from experiments exploring $O A$ effects on growth, calcification, and photosynthesis in tropical benthic macroalgae. Only business-as-usual OA experiments (800-1200 $\mu \mathrm{atm})$ are included. + : positive effect, -: negative effect, $0:$ no effect 
Table 5. OA effects on tropical benthic macroalgae.

\begin{tabular}{|c|c|c|c|c|}
\hline Species & $\begin{array}{c}\text { Growth/Calcificatio } \\
\mathrm{n}\end{array}$ & Photosynthesis & Reproduction & Reference \\
\hline \multicolumn{5}{|l|}{ Fleshy macroalgae } \\
\hline Acanthophora spicifera & 0 & - & + & this study \\
\hline Avrainvidea amadelpha & - & & + & this study \\
\hline Caulerpaserrulata 2010 & + & 0 & & this study \\
\hline Caulerpwserrulata 2011 & 0 & 0 & + & this study \\
\hline Dictyotabartayresiana & + & 0 & & this study \\
\hline Hypnea-gannosa & + & 0 & & this study \\
\hline 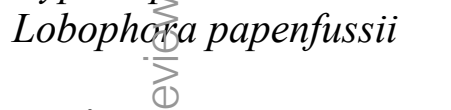 & - & & & $\frac{\text { (Diaz-Pulido et al. }}{\underline{2011} \text { ) }}$ \\
\hline Uprightcalcareous algae & & & & \\
\hline Galaxaura rugosa & 0 & + & & this study \\
\hline Dichotomaria marginata & - & 0 & & this study \\
\hline Halimerd opuntia & - & 0 & & this study \\
\hline Halime taenicola & 0 & 0 & & this study \\
\hline Halima cylindracea & - & - & & $\begin{array}{l}\text { (Sinutok et al. 2011; } \\
\text { Sinutok et al. 2012)2 }\end{array}$ \\
\hline Halimeda macroloba & - & - & & $\begin{array}{l}\text { (Sinutok et al. 2011; } \\
\text { Sinutok et al. 2012) }\end{array}$ \\
\hline Halimeda incrassata & + & & & (Ries et al. 2009) \\
\hline Lithophyllum prototypum & - & 0 & & this study \\
\hline Lithophyllum sp. & - & 0 & & this study \\
\hline Hydrolithon sp. & - & + & & (Semesi et al. 2009) \\
\hline Porolithon onkodes & - & - & & $\begin{array}{c}\text { (Anthony et al. 2008) } \\
\text { (Diaz-Pulido et al. } \\
\text { 2012; Johnson and } \\
\text { Carpenter 2012; } \\
\text { Comeau et al. 2013a; } \\
\text { Comeau et al. 2013b) }\end{array}$ \\
\hline
\end{tabular}


Neogoniolithon sp.

Mixed CCA

$+$

(Ries et al. 2009)

(Jokiel et al. 2008;

Kuffner et al. 2008)

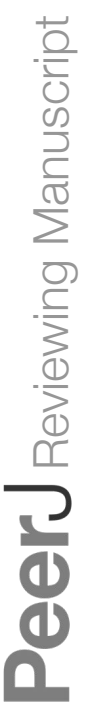

